\title{
Global Budgets of Atmospheric Glyoxal and Methylglyoxal, and Implications for Formation of Secondary Organic Aerosols
}

\section{Citation}

Fu, Tzung-May, Daniel J. Jacob, Folkard Wittrock, John P. Burrows, Mihalis Vrekoussis, and Daven K. Henze. 2008. Global budgets of atmospheric glyoxal and methylglyoxal, and implications for formation of secondary organic aerosols. Journal of Geophysical Research 113(D15303): 1-17.

\section{Published Version}

doi:10.1029/2007JD009505

\section{Permanent link}

http://nrs.harvard.edu/urn-3:HUL.InstRepos:3554394

\section{Terms of Use}

This article was downloaded from Harvard University's DASH repository, and is made available under the terms and conditions applicable to Other Posted Material, as set forth at http:// nrs.harvard.edu/urn-3:HUL.InstRepos:dash.current.terms-of-use\#LAA

\section{Share Your Story}

The Harvard community has made this article openly available.

Please share how this access benefits you. Submit a story.

Accessibility 


\title{
Global budgets of atmospheric glyoxal and methylglyoxal, and implications for formation of secondary organic aerosols
}

\author{
Tzung-May Fu, ${ }^{1,2}$ Daniel J. Jacob, ${ }^{1}$ Folkard Wittrock, ${ }^{3}$ John P. Burrows, ${ }^{3}$ \\ Mihalis Vrekoussis, ${ }^{3}$ and Daven K. Henze ${ }^{4}$ \\ Received 16 October 2007; revised 11 February 2008; accepted 4 April 2008; published 2 August 2008.
}

[1] We construct global budgets of atmospheric glyoxal and methylglyoxal with the goal of quantifying their potential for global secondary organic aerosol (SOA) formation via irreversible uptake by aqueous aerosols and clouds. We conduct a detailed simulation of glyoxal and methylglyoxal in the GEOS-Chem global 3-D chemical transport model including our best knowledge of source and sink processes. Our resulting best estimates of the global sources of glyoxal and methylglyoxal are $45 \mathrm{Tg} \mathrm{a}^{-1}$ and $140 \mathrm{Tg} \mathrm{a}^{-1}$, respectively. Oxidation of biogenic isoprene contributes globally $47 \%$ of glyoxal and $79 \%$ of methylglyoxal. The second most important precursors are acetylene (mostly anthropogenic) for glyoxal and acetone (mostly biogenic) for methylglyoxal. Both acetylene and acetone have long lifetimes and provide a source of dicarbonyls in the free troposphere. Atmospheric lifetimes of glyoxal and methylglyoxal in the model are $2.9 \mathrm{~h}$ and $1.6 \mathrm{~h}$, respectively, mostly determined by photolysis. Simulated dicarbonyl concentrations in continental surface air at northern midlatitudes are in the range 10-100 ppt, consistent with in situ measurements. On a global scale, the highest concentrations are over biomass burning regions, in agreement with glyoxal column observations from the SCIAMACHY satellite instrument. SCIAMACHY and a few ship cruises also suggest a large marine source of dicarbonyls missing from our model. The global source of SOA from the irreversible uptake of dicarbonyls in GEOS-Chem is $11 \mathrm{Tg} \mathrm{C}^{-1}$, including $2.6 \mathrm{Tg} \mathrm{C}^{-1}$ from glyoxal and $8 \mathrm{Tg} \mathrm{C}^{-1}$ from methylglyoxal; $90 \%$ of this source takes place in clouds. The magnitude of the global SOA source from dicarbonyls is comparable to that computed in GEOS-Chem from the standard mechanism involving reversible partitioning of semivolatile products from the oxidation of monoterpenes, sesquiterpenes, isoprene, and aromatics.

Citation: Fu, T.-M., D. J. Jacob, F. Wittrock, J. P. Burrows, M. Vrekoussis, and D. K. Henze (2008), Global budgets of atmospheric glyoxal and methylglyoxal, and implications for formation of secondary organic aerosols, J. Geophys. Res., 113, D15303, doi:10.1029/ 2007JD009505.

\section{Introduction}

[2] Organic aerosols constitute a major component of atmospheric aerosols and have large impacts on atmospheric chemistry, air quality, and climate. Primary organic aerosol is directly emitted into the atmosphere by combustion. Secondary organic aerosol (SOA) is produced in the atmosphere by oxidation of volatile organic compounds (VOCs) [Kanakidou et al., 2005]. We examine here the potential of

\footnotetext{
${ }^{1}$ Department of Earth and Planetary Sciences, Harvard University, Cambridge, Massachusetts, USA.

${ }^{2}$ Now at Department of Civil and Structural Engineering, The Hong Kong Polytechnic University, Hung Hom, Kowloon, Hong Kong.

${ }^{3}$ Institute of Environmental Physics and Remote Sensing, University of Bremen, Bremen, Germany.

${ }^{4}$ NASA Goddard Institute for Space Studies and the Earth Institute, Columbia University, New York, New York, USA.
}

Copyright 2008 by the American Geophysical Union. 0148-0227/08/2007JD009505\$09.00 glyoxal (CHOCHO) and methylglyoxal $\left(\mathrm{CH}_{3} \mathrm{C}(\mathrm{O}) \mathrm{CHO}\right)$, the two smallest dicarbonyl compounds, as global sources of SOA. Both are produced in the atmosphere from the oxidation of many VOCs, and both are highly soluble in water. Several laboratory and photochemical model studies have recently suggested that the uptake of these dicarbonyls by aqueous aerosols and clouds, followed by oxidation and/ or oligomerization, could be a significant source of SOA. We construct here global atmospheric budgets of glyoxal and methylglyoxal and infer the resulting SOA source.

[3] The standard approach used in global models to describe SOA production involves reversible gas-aerosol partitioning of the semivolatile oxidation products of VOC precursors [Pankow, 1994a, 1994b; Odum et al., 1996]. Current models include as VOC precursors isoprene, terpenes, and aromatic compounds [Chung and Seinfeld, 2002; Henze and Seinfeld, 2006; Liao et al., 2007; Henze et al., 2008]. Recent measurements have shown that these models underestimate SOA, particularly in the remote atmosphere 
[Heald et al., 2005; Volkamer et al., 2006; Kleinman et al., 2007], and do not reproduce the observed variability of SOA concentrations [Heald et al., 2006b]. On the basis of constraints on the global deposition of organic carbon, Goldstein and Galbally [2007] estimate that over $175 \mathrm{Tg} \mathrm{C} \mathrm{a}^{-1}$ is deposited to Earth's surface as SOA, an order of magnitude greater than currently predicted from the standard approach.

[4] Recent work has identified the potential importance of glyoxal and methylglyoxal for SOA formation by a different pathway. Both dicarbonyls are produced with high yield from the oxidation of a number of biogenic and anthropogenic VOCs. They have short lifetimes $(\sim 2 \mathrm{~h}$ in daytime) against photolysis and oxidation by $\mathrm{OH}$, but can also be taken up by aqueous aerosols and cloud droplets on account of their high water solubility [Betterton and Hoffmann, 1988; Zhou and Mopper, 1990a]. Chamber experiments by Schweitzer et al. [1998] and Liggio et al. [2005a, 2005b] showed irreversible first-order uptake of glyoxal by aqueous particles with a reactive uptake coefficient $\gamma \sim 10^{-3}$. A similar $\gamma$ was measured for methylglyoxal in acidic solutions [Zhao et al., 2006]. Volkamer et al. [2007] found that measured gas-phase glyoxal concentrations in Mexico City are significantly below gas-phase model predictions, and that the difference can be resolved by invoking a SOA sink for glyoxal. On the other hand, chamber studies by Kroll et al. [2005] found uptake of glyoxal by aerosols to be reversible, with no significant SOA production. They also found no significant uptake of methylglyoxal by aerosols. An aqueous-phase SOA source from glyoxal and methylglyoxal would be consistent with field observations linking SOA mass with aqueous-phase processes [Crahan et al., 2004; Yu et al., 2005; Zhang et al., 2005; Sorooshian et al., 2006; Yuan et al., 2006; Lanz et al., 2007].

[5] Three aqueous-phase chemical processes could lead to irreversible uptake of glyoxal and methylglyoxal by aqueous aerosols and cloud droplets. The first involves oxidation to form nonvolatile organic acids such as glyoxylic, pyruvic, and oxalic acids [Crahan et al., 2004; Ervens et al., 2004; Lim et al., 2005; Warneck, 2005; Carlton et al., 2006; Sorooshian et al., 2006, 2007; Carlton et al., 2006, 2007]. The second involves oligomerization of the dicarbonyls [Schweitzer et al., 1998; Kalberer et al., 2004; Liggio et al., 2005a, 2005b; Hastings et al., 2005; Zhao et al., 2006; Loeffler et al., 2006]. Barsanti and Pankow [2005] showed that SOA formation by oligomerization and aldol condensation is thermodynamically favorable for both glyoxal and methylglyoxal at atmospheric concentrations. The third involves aqueous-phase oxidation of the dicarbonyls to organic acids which then oligomerize [Altieri et al., 2006, 2008]. These three processes have the potential to account for the high oligomer and organic acid concentrations detected in ambient aerosols [Kalberer et al., 2004; Lim et al., 2005; Warneck, 2005; Sorooshian et al., 2006; Carlton et al., 2007; Denkenberger et al., 2007].

[6] We present here a detailed analysis of the global budgets of atmospheric glyoxal and methylglyoxal with the goal of quantifying their potential contribution to SOA formation. We construct a global simulation for both dicarbonyls based on current knowledge of their precursors and chemistry, and compare model results to the few available observations. We then examine the consequences of irreversible uptake by aqueous aerosols and clouds, drawing from the work of Liggio et al. [2005b], to determine the resulting SOA source in aqueous particles and cloud droplets.

\section{Model Framework}

[7] We use the GEOS-Chem global 3-D chemical transport model (version 7.3.6; http:/www-as.harvard.edu/chemistry/ trop/geos/) to simulate the global distributions of glyoxal and methylglyoxal from June 2005 to November 2006. The first six months initialize the model. Results from December 2005 to November 2006 are analyzed. The model is driven by assimilated meteorological data from the Goddard Earth Observing System (GEOS-4) of the NASA Global Modeling Assimilation Office [Bey et al., 2001]. The meteorological data are available with a temporal resolution of $6 \mathrm{~h}(3 \mathrm{~h}$ for surface variables and mixing depths), a horizontal resolution of $1^{\circ}$ latitude $\times 1.25^{\circ}$ longitude, and 55 vertical levels extending up to $0.01 \mathrm{hPa}$. For driving GEOS-Chem simulations, we regrid here the horizontal resolution to $4^{\circ}$ latitude $\times 5^{\circ}$ longitude.

[8] We use the Master Chemistry Mechanism version 3.1 (MCMv3.1) [Saunders et al., 2003; Bloss et al., 2005] as principal guide for the VOC chemistry leading to glyoxal and methylglyoxal formation. Primary VOC precursors include isoalkanes, alkenes, acetylene, aromatics, isoprene, monoterpenes, acetone, methylbutenol (2-methyl-3-buten-2-ol), glycolaldehyde, and hydroxyacetone. The latter two are secondary products of VOC oxidation but are also emitted directly by biofuel use and open biomass burning. Glyoxal and methylglyoxal are themselves also emitted directly from these two sources [McDonald et al., 2000; Hays et al., 2002]. Primary anthropogenic emissions of glyoxal and methylglyoxal are small [Environmental Protection Agency, 2004; Volkamer et al., 2005b] and are not considered here. Table 1 summarizes the global emissions of the dicarbonyl precursors used in this study and details are given in section 3 .

[9] GEOS-Chem includes a detailed $\mathrm{O}_{3}-\mathrm{NO}_{\mathrm{x}}$-VOC-aerosol chemical mechanism [Horowitz et al., 1998; Bey et al., 2001; Martin et al., 2003; Park et al., 2006]. Hydrocarbons in the standard GEOS-Chem model include methane, ethane, propane, $>\mathrm{C}_{3}$ alkanes (as lumped n-butane), $>\mathrm{C}_{2}$ alkenes (as lumped propene), isoprene, and monoterpenes (as formaldehyde precursors). Fu et al. [2007] added to the model the chemistry of ethylene and xylenes. For this work, we further updated the photochemical mechanisms of isoprene, propene, acetylene, glyoxal, methylglyoxal, glycolaldehyde, and hydroxyacetone based on MCMv3.1 and Jet Propulsion Laboratory (JPL) [2006]. The quantum yield for acetone photolysis is updated to be dependent on both temperature and pressure, based on Blitz et al. [2004]. We also added parameterized dicarbonyl production from benzene, toluene, xylenes, monoterpenes, and methylbutenol. These updates and additions will be described in sections 3 and 4.

[10] Current understanding of VOC atmospheric chemistry is mainly based on the "high- $\mathrm{NO}_{\mathrm{x}}$ " regime where organic peroxy radicals $\left(\mathrm{RO}_{2}\right)$ react with $\mathrm{NO}$ to produce oxy radicals (RO) and eventually carbonyls [Atkinson, 2000]. Under low- $\mathrm{NO}_{\mathrm{x}}$ conditions, the $\mathrm{RO}_{2}$ radicals react instead mostly with $\mathrm{HO}_{2}$ to form organic hydroperoxides (ROOH). Standard mechanisms such as MCMv3.1 (as used 
Table 1. Global Sources of Glyoxal, Methylglyoxal, and Their Atmospheric Precursors ${ }^{\mathrm{a}}$

\begin{tabular}{|c|c|c|c|c|c|c|c|c|c|}
\hline \multirow[b]{2}{*}{ Precursor } & \multicolumn{5}{|c|}{ Emissions, $\mathrm{Tg} \mathrm{a}^{-1}$} & \multicolumn{2}{|c|}{ Glyoxal Production } & \multicolumn{2}{|c|}{$\begin{array}{c}\text { Methylglyoxal } \\
\text { Production }\end{array}$} \\
\hline & Anthropogenic ${ }^{b}$ & $\begin{array}{c}\text { Biofuel } \\
\text { Use }^{c}\end{array}$ & $\begin{array}{l}\text { Biomass } \\
\text { Burning }^{\mathrm{d}}\end{array}$ & Biogenic & Total & $\begin{array}{c}\text { Molar } \\
\text { yield }^{\mathrm{e}}, \%\end{array}$ & $\begin{array}{c}\text { Production, } \\
\mathrm{Tg} \mathrm{a}^{-1}\end{array}$ & $\begin{array}{c}\text { Molar } \\
\text { yield }^{\mathrm{e}}, \%\end{array}$ & $\begin{array}{c}\text { Production, } \\
\mathrm{Tg} \mathrm{a}^{-1} \\
\end{array}$ \\
\hline Isoprene & . & . & . & $410^{\mathrm{f}}$ & 410 & 6.2 & 21 & 25 & 110 \\
\hline Acetone (primary) & 1.1 & 0.40 & 3.0 & $53^{\mathrm{g}}$ & 57 & . & . & 14 & 10 \\
\hline Acetylene & $1.7^{\mathrm{h}}$ & $3.1^{\mathrm{h}}$ & $1.5^{\mathrm{h}}$ & . & 6.3 & 64 & 8.9 & . & . \\
\hline Glyoxal (primary) & . & $2.4^{\mathrm{i}}$ & $5.2^{\mathrm{i}}$ & . & 7.7 & 100 & 7.7 & . & . \\
\hline Methylglyoxal (primary) & & $1.6^{\mathrm{i}}$ & $3.4^{\mathrm{i}}$ & & 5.0 & . & & 100 & 5.0 \\
\hline$>\mathrm{C}_{2}$ alkenes $^{\mathrm{j}}$ & 8.3 & 7.3 & 3.6 & $12^{\mathrm{k}}$ & 31 & . & . & 7.7 & 4.1 \\
\hline Hydroxyacetone (primary) & $\cdot$ & $1.5^{1}$ & $3.3^{1}$ & . & 4.9 & . & & 75 & 3.6 \\
\hline Ethylene & 2.6 & 2.8 & 6.0 & $9.6^{\mathrm{m}}$ & 21 & 5.7 & 2.5 & . & . \\
\hline Monoterpenes & & . & . & $160^{\mathrm{n}}$ & 160 & 2.8 & 1.8 & 4.2 & 3.5 \\
\hline Propane & 13 & 1.1 & 2.1 & . & 16 & & . & 11 & 2.7 \\
\hline$>\mathrm{C}_{3}$ alkanes ${ }^{\mathrm{O}}$ & 24 & 0.91 & 0.91 & . & 26 & . & . & 3.2 & 1.0 \\
\hline Benzene & 1.4 & 2.0 & 1.5 & . & 4.8 & 25 & 0.90 & . & . \\
\hline Toluene & 4.6 & 1.2 & 0.93 & . & 6.7 & 16 & 0.68 & 12 & 0.65 \\
\hline Xylenes & 3.8 & 0.55 & 0.28 & . & 4.7 & 16 & 0.39 & 23 & 0.73 \\
\hline Glycolaldehyde (primary) & . & 1.4 & 4.3 & . & 5.6 & 9.9 & 0.54 & . & . \\
\hline Methylbutenol & . & $\cdot$ & · & 9.6 & 9.6 & 5.4 & 0.34 & 6.2 & 0.5 \\
\hline Total source & & & & & & & 45 & & 140 \\
\hline
\end{tabular}

${ }^{\mathrm{a}}$ From the GEOS-Chem global model simulation described in the text.

${ }^{b}$ Not including biofuel and biomass burning, which are accounted for in separate columns. Unless otherwise noted, anthropogenic emissions are based on the EDGARv2.0 inventory with $1^{\circ} \times 1^{\circ}$ horizontal resolution for year 1990 [Olivier et al., 1996, 1999], and are then scaled to year 2000 using national $\mathrm{CO}_{2}$ emissions from liquid fuel use following Bey et al. [2001].

${ }^{\mathrm{c}}$ Biofuel emissions are based on a global CO emission inventory of $180 \mathrm{Tg} \mathrm{y}^{-1}$ with $1^{\circ} \times 1^{\circ}$ horizontal resolution from Yevich and Logan [2003]. Unless otherwise noted, emission ratios relative to CO are taken from Andreae and Merlet [2001] and M. O. Andreae [personal communication, 2006].

${ }^{\mathrm{d}}$ Biomass burning emissions are based on a global $\mathrm{CO}$ emission inventory of $400 \mathrm{Tg} \mathrm{a} \mathrm{a}^{-1}$ with $1^{\circ} \times 1^{\circ}$ horizontal resolution and monthly temporal resolution from the Global Fire Emissions Database version2 (GFEDv2) [van der Werf et al., 2006]. Unless otherwise noted, emission ratios are taken from Andreae and Merlet [2001] and M. O. Andreae [personal communication, 2006].

${ }^{\mathrm{e}} \mathrm{Global}$ annual mean molar yield as calculated by GEOS-Chem.

${ }_{\mathrm{f}}^{\mathrm{f}}$ From the MEGAN inventory [Guenther et al., 2006].

${ }_{\mathrm{g}}^{\mathrm{g}}$ Including $29 \mathrm{Tg} \mathrm{a}^{-1}$ from terrestrial vegetation and $24 \mathrm{Tg} \mathrm{a}^{-1}$ from photochemical decomposition of dissolved organic matter in the ocean $[\mathrm{Jacob}$ et al., 2002].

${ }^{\mathrm{h}}$ Anthropogenic emission and biofuel and biomass burning emission ratios from Xiao et al. [2007].

${ }^{\mathrm{i}}$ Emission ratios from Hays et al. [2002].

${ }^{j}>\mathrm{C}_{2}$ alkenes are represented in GEOS-Chem as a single lumped species with the reactivity of propene.

${ }^{\mathrm{k}}$ From Wang et al. [1998].

${ }^{1}$ Emission ratio from Christian et al. [2003].

${ }^{\mathrm{m}}$ From Wang et al. [1998]. Marine emission of ethylene, estimated to be $1.4 \mathrm{Tg} \mathrm{a}^{-1}$ [Plass-Dülmer et al., 1995], is not included.

${ }^{\mathrm{n}}$ From the GEIA inventory [Guenther et al., 1995; Wang et al., 1998].

${ }^{\circ}>C_{3}$ alkanes are represented in GEOS-Chem as a single lumped species with the reactivity of n-butane.

in GEOS-Chem) assume that the ROOH compounds react with $\mathrm{OH}$ by abstraction at the hydroperoxy group or photolyze at the peroxy bond on a timescale of the order of a day, returning $\mathrm{RO}_{2}$ and $\mathrm{RO}$ and eventually yielding the same carbonyl products as in the high- $\mathrm{NO}_{\mathrm{x}}$ regime but with delay. There is some support for this assumption from field observations [Thornton et al., 2002; Palmer et al., 2003]. The upshot is that the ultimate dicarbonyl yield from VOC oxidation in GEOS-Chem depends little on $\mathrm{NO}_{\mathrm{x}}$ levels (there is some minor dependence from $\mathrm{RO}_{2}$ permutation reactions under low- $\mathrm{NO}_{\mathrm{x}}$ conditions). The two exceptions are acetone and propene for which the $\mathrm{RO}_{2}+\mathrm{HO}_{2}$ reactions in MCMv3.1 produce hydroxyacetone and methylglyoxal in addition to hydroperoxides.

[11] We describe in section 4 the inclusion in GEOSChem of SOA production from irreversible uptake of dicarbonyls. In addition, GEOS-Chem includes SOA formation by the standard approach involving reversible partitioning of semivolatile oxidation products from terpenes, terpenoid alcohols, sesquiterpenes, and isoprene, based on the algorithm by Chung and Seinfeld [2002] [Tsigaridis and Kanakidou, 2003, 2007; Heald et al., 2005; Henze and
Seinfeld, 2006; Liao et al., 2007]. We allow the reversible gas-particle partitioning to occur in both organic and aqueous particles to provide an upper limit for this process [Park et al., 2006]. Henze et al. [2008] recently added to GEOSChem the SOA formation from reversible partitioning of aromatic oxidation products, but found that it makes only a small contribution on the global scale and we do not include it in the current study. Although it is not clear that SOA formation by the reversible and irreversible pathways can be viewed as additive (we will return to that point in section 6), inclusion of the two pathways in GEOS-Chem allows comparison of their respective magnitudes.

[12] Dry deposition of aerosols and gases in GEOS-Chem uses a standard resistance-in-series model dependent on species properties, local surface type, and meteorological information [Wesely, 1989], and is implemented as described by Wang et al. [1998]. The wet deposition mechanism for aerosols in GEOS-Chem is described by Liu et al. [2001], and is extended to water-soluble gases according to their effective Henry's Law coefficient for warm clouds, their retention efficiency upon freezing for mixed clouds, and surface coating or cocondensation with water ice for 


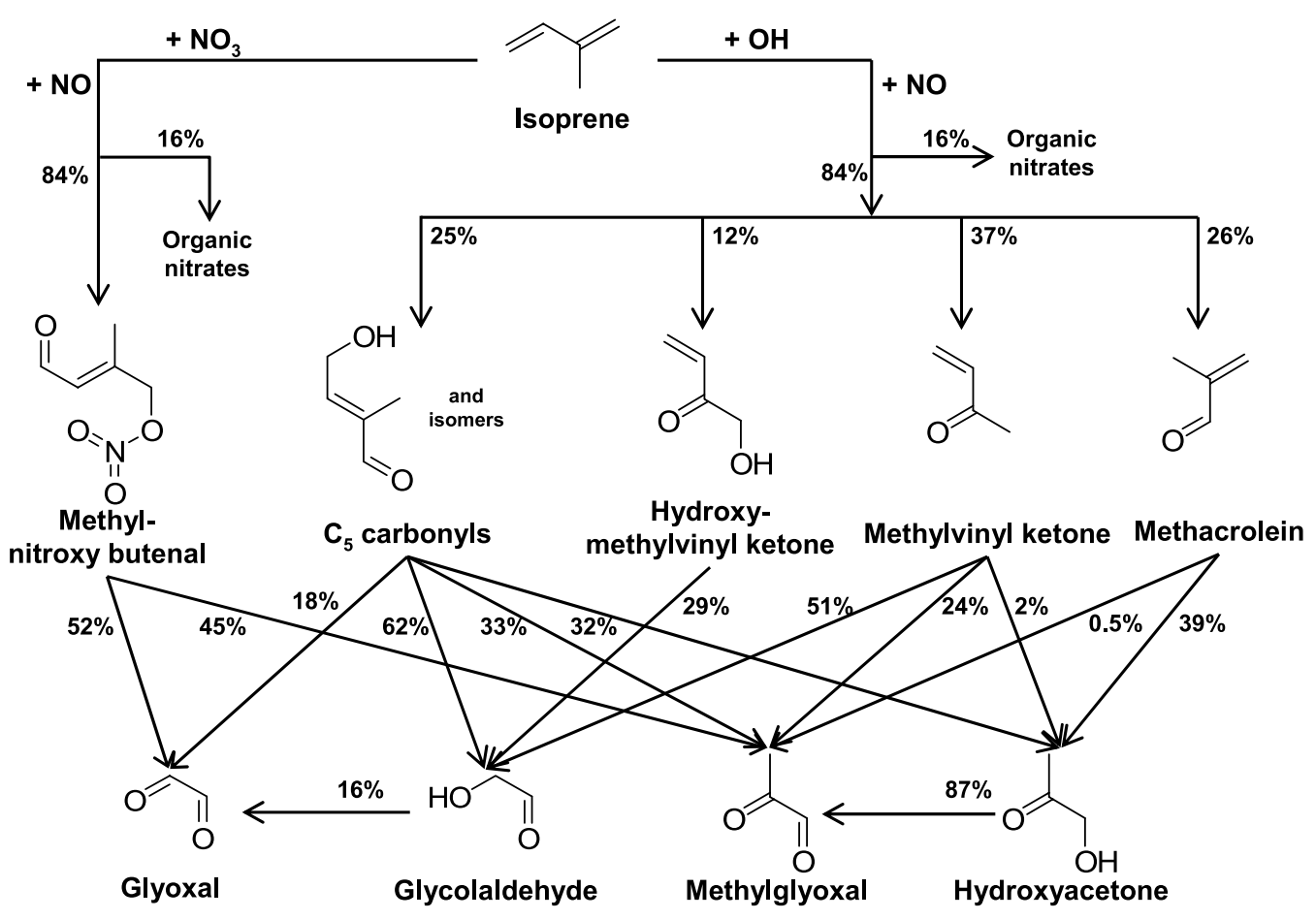

Figure 1. Glyoxal and methylglyoxal production from the oxidation of isoprene by $\mathrm{OH}$ and $\mathrm{NO}_{3}$. The molar yields, shown in percentages, are calculated using the chemical mechanism in GEOS-Chem based on MCMv3.1 [Saunders et al., 2003; Bloss et al., 2005]. The diagram assumes that organic peroxy radicals $\left(\mathrm{RO}_{2}\right)$ react with $\mathrm{NO}$ only; as discussed in the text, reaction with $\mathrm{HO}_{2}$ to form peroxides does not change the ultimate product yields. The branching ratios for carbonyl decomposition are computed assuming $\left[\mathrm{O}_{3}\right]=40 \mathrm{ppb},[\mathrm{OH}]=4 \times 10^{6}$ molecules $\mathrm{cm}^{-3}$, and July mean surface photolysis rates at $45^{\circ} \mathrm{N}$ latitude at noon.

cold clouds [Mari et al., 2000]. Specifics for deposition of glyoxal and methylglyoxal will be presented in section 4 .

\section{Sources of Glyoxal and Methylglyoxal}

[13] Table 1 summarizes the emissions of the primary precursors of glyoxal and methylglyoxal used in this study, their dicarbonyl yields as calculated by the model (separating the contribution from each precursor), and the resulting contributions to the global dicarbonyl budgets. We elaborate below on each of these sources.

\subsection{Isoprene Oxidation}

[14] Isoprene is the most important precursor for both dicarbonyls, contributing $47 \%$ of glyoxal and $79 \%$ of methylglyoxal globally. Our detailed isoprene oxidation mechanism in GEOS-Chem is adapted from MCMv3.1 and is illustrated in Figure 1. Oxidation by $\mathrm{NO}_{3}$ produces both dicarbonyls with high yields but accounts for only a small fraction of isoprene loss. Oxidation by $\mathrm{OH}$ yields glyoxal and methylglyoxal as second-generation products and also as third-generation products via the intermediates glycolaldehyde $\left(\mathrm{HOCH}_{2} \mathrm{CHO}\right)$ and hydroxyacetone $\left(\mathrm{HOCH}_{2} \mathrm{C}(\mathrm{O}) \mathrm{CH}_{3}\right)$. In the presence of $\mathrm{NO}$, glyoxal and methylglyoxal are produced in a matter of hours following isoprene oxidation. Under low $\mathrm{NO}_{\mathrm{x}}$ conditions, the dicarbonyl production can be delayed for days due to formation of $\mathrm{ROOH}$ reservoirs. The global mean molar yields of glyoxal from isoprene are $4.6 \%$ as a second generation product and $1.6 \%$ as a third generation product. The mean molar yields of methylglyoxal from isoprene are $13 \%$ as a second generation product and $11 \%$ as a third generation product. Global biogenic isoprene emission estimated by MEGAN [Guenther et al., 2006] is $410 \mathrm{Tg} \mathrm{a}^{-1}$, producing $21 \mathrm{Tg} \mathrm{a}^{-1}$ glyoxal and $110 \mathrm{Tg} \mathrm{a}^{-1}$ methylglyoxal.

[15] We elaborate further on the dicarbonyl production from glycolaldehyde and hydroxyacetone, as these compounds are produced from the oxidation of a number of VOCs discussed below and are also directly emitted from biomass burning (Table 1). Both are removed by photolysis and oxidation by $\mathrm{OH}$, the latter process producing glyoxal and methylglyoxal [Orlando et al., 1999; Bacher et al., 2001; Magneron et al., 2005; JPL, 2006]:

$$
\begin{aligned}
\mathrm{HOCH}_{2} \mathrm{CHO}+\mathrm{OH} \rightarrow & 0.2 \mathrm{CHOCHO}+0.2 \mathrm{HO}_{2} \\
& +0.80 \mathrm{HOCH}_{2} \mathrm{C}(\mathrm{O}) \mathrm{OO} \bullet
\end{aligned}
$$

$$
\mathrm{HOCH}_{2} \mathrm{C}(\mathrm{O}) \mathrm{CH}_{3}+\mathrm{OH} \rightarrow \mathrm{CH}_{3} \mathrm{C}(\mathrm{O}) \mathrm{CHO}+\mathrm{HO}_{2}+\mathrm{H}_{2} \mathrm{O}
$$

A recent laboratory study found that the molar yield of methylglyoxal from hydroxyacetone oxidation in reaction (2) is temperature-dependent and decreases from $82 \%$ at $298 \mathrm{~K}$ to $49 \%$ at 236K [Butkovskaya et al., 2006]. Here we assume this yield to be unity following MCMv3.1. Rate constants for $\mathrm{OH}$ oxidation are $1.1 \times 10^{-11} \mathrm{~cm}^{3}$ molecule ${ }^{-1} \mathrm{~s}^{-1}$ 
for glycolaldehyde [Bacher et al., 2001] and $3 \times 10^{-12}$ $\mathrm{cm}^{3}$ molecule ${ }^{-1} \mathrm{~s}^{-1}$ for hydroxyacetone [Orlando et al., 1999]. Glycolaldehyde is also oxidized by $\mathrm{NO}_{3}$ with a rate constant of $1.44 \times 10^{-12} \exp (-1862 / T)$ [MCMv3.1], not producing glyoxal. Photolysis frequencies for glycoladehyde and hydroxyacetone are calculated using absorption cross sections and quantum yield data from JPL [2006]. Glycolaldehyde is sufficiently water-soluble to be removed by dry and wet deposition, with an effective Henry's Law constant $H^{*}=4.1 \times 10^{4} \exp \left[4.6 \times 10^{3}(1 / T-1 / 298)\right]$ $\mathrm{M} \mathrm{atm}^{-1}$ accounting for hydrolysis [Betterton and Hoffmann, 1988]. On a global scale, the molar yield of glyoxal from glycolaldehyde is $9.9 \%$ and the molar yield of methylglyoxal from hydroxyacetone is $75 \%$.

\subsection{Other Sources}

[16] Acetone is the second largest source of methylglyoxal and has a long atmospheric lifetime (22 d against $\mathrm{OH}$ oxidation and photolysis in GEOS-Chem), enabling SOA production in the free troposphere. Primary sources of acetone are mainly biogenic, including terrestrial vegetation and dissolved organic matter in the ocean [Jacob et al., 2002]. In addition, acetone is produced in the atmosphere by $\mathrm{OH}$ oxidation of monoterpenes, methylbutenol, and isoalkanes; these secondary sources will be discussed below. Acetone oxidation by $\mathrm{OH}$ in $\mathrm{MCMv3.1}$ produces methylglyoxal and hydroxyacetone when $\mathrm{NO}_{\mathrm{x}}$ is low, as a result of the $\mathrm{RO}_{2}$ radicals reacting with $\mathrm{HO}_{2}$ or with other $\mathrm{RO}_{2}$ radicals. Annual methylglyoxal production from primary acetone is $10 \mathrm{Tg} \mathrm{a}^{-1}$, contributing $7 \%$ of the global total methylglyoxal source.

[17] Several monoterpenes including $\alpha$-pinene, $\Delta^{3}$-carene, geraniol, and citral produce glyoxal and methylglyoxal when oxidized by ozone [Yu et al., 1998; Fick et al., 2003, 2004; Nunes et al., 2005]. Measured molar yields for $\alpha$-pinene ozonolysis range from $4 \%$ to $9 \%$ for glyoxal and $1 \%$ to $11 \%$ for methylglyoxal and appear to be sensitive to temperature and relative humidity [Fick et al., 2003, 2004]. We assume an instantaneous and constant molar yield of 5\% for both dicarbonyls from all monoterpenes when oxidized by $\mathrm{O}_{3}$. In addition, monoterpene oxidation by both $\mathrm{OH}$ and $\mathrm{O}_{3}$ produces $6.9 \mathrm{Tg} \mathrm{a}^{-1}$ acetone [Jacob et al., 2002], which further oxidizes to produce methylglyoxal. Global emission of monoterpenes is $160 \mathrm{Tg} \mathrm{a}^{-1}$ in the GEIA inventory [Guenther et al., 1995]. The mean overall molar yield of glyoxal from oxidation of monoterpenes is $2.8 \%$, producing $1.8 \mathrm{Tg} \mathrm{a}^{-1}$ glyoxal. The corresponding mean molar yield of methylglyoxal is $4.2 \%$, producing $3.5 \mathrm{Tg} \mathrm{a}^{-1}$ methylglyoxal.

[18] Methylbutenol (MBO), emitted by North American pine trees, is oxidized by $\mathrm{OH}$ with a global mean lifetime of $7.1 \mathrm{~h}$ to produce glycolaldehyde and from there glyoxal. The reported molar yields of glycolaldehyde from $\mathrm{MBO}$ under high- $\mathrm{NO}_{\mathrm{x}}$ conditions range from $50 \%$ to $78 \%$ [Atkinson and Arey, 2003; Carrasco et al., 2007]. We assume a constant molar yield of $63 \%$ following MCMv3.1. In addition, MBO oxidation produces $2.5 \mathrm{Tg} \mathrm{a}^{-1}$ acetone [Jacob et al., 2002], which can then produce methylglyoxal as described above. Global MBO emission is $9.6 \mathrm{Tg} \mathrm{a}^{-1}$ in the GEIA inventory, all from North America [Guenther et al., 1995], producing $0.35 \mathrm{Tg} \mathrm{a}^{-1}$ glyoxal and $0.5 \mathrm{Tg} \mathrm{a}^{-1}$ methylglyoxal.
[19] $\mathrm{C}_{3}-\mathrm{C}_{5}$ isoalkanes (propane, isobutane, isopentane) are mostly anthropogenic and are oxidized in the atmosphere by $\mathrm{OH}$ to produce methylglyoxal by way of acetone [Jacob et al., 2002]. Propane produces acetone with 75\% yield. Global propane emission is $16 \mathrm{Tg} \mathrm{a}^{-1}$, which produces $2.7 \mathrm{Tg} \mathrm{a}^{-1}$ methylglyoxal. Higher isoalkanes contribute an additional $1.0 \mathrm{Tg} \mathrm{a}^{-1}$ methylglyoxal.

[20] Ethylene and higher alkenes are emitted by vegetation and human activities. Ethylene $\left(\mathrm{C}_{2} \mathrm{H}_{4}\right)$ is mainly oxidized by $\mathrm{OH}$ with a mean lifetime of $1.7 \mathrm{~d}$ and produces glycolaldehyde, precursor to glyoxal. GEOS-Chem includes detailed ethylene photochemistry based on MCMv3.1 [Fu et $a l ., 2007]$. The yield of glycolaldehyde is determined by the branching of $\mathrm{HOC}_{2} \mathrm{H}_{4} \mathrm{O}$ radical decomposition, which depends on temperature and pressure [IUPAC, 2006]. As a result, the yield of glycolaldehyde from ethylene ranges from approximately $30 \%$ at the surface to near $100 \%$ in the upper troposphere. The global average molar yield of glyoxal from ethylene is $5.7 \%$, producing $2.5 \mathrm{Tg} \mathrm{a}$ glyoxal.

[21] The only higher $\left(>\mathrm{C}_{2}\right)$ alkene that produces significant amounts of dicarbonyls according to MCMv3.1 is propene, which is oxidized by $\mathrm{OH}$ to form $\beta$-hydroxyalkyl peroxy radicals. Under low $\mathrm{NO}_{\mathrm{x}}$ conditions, these radicals can react with $\mathrm{HO}_{2}$ or other $\mathrm{RO}_{2}$ radicals to form hydroxyacetone. The oxidation of isoalkenes by $\mathrm{OH}$ produces acetone but is a negligibly small source [Jacob et al., 2002]. GEOS-Chem represents all higher alkenes as one single lumped species with the reactivity of propene. We scale the hydroxyacetone yield from propene in our chemical mechanism by assuming the molar ratio of propene to higher alkenes to be 1.5 , based on the emission ratios from EDGARv2.0 and Goldstein et al. [1996]. The resulting global average yield of methylglyoxal from higher alkenes is $7.7 \%$, producing methylglyoxal at a rate of $4.1 \mathrm{Tg} \mathrm{a}^{-1}$.

[22] Acetylene $\left(\mathrm{C}_{2} \mathrm{H}_{2}\right)$ is the second largest source of glyoxal and the most important anthropogenic precursor [Xiao et al., 2007]. It is emitted by combustion and has a global mean lifetime of $18 \mathrm{~d}$ against oxidation by $\mathrm{OH}$. The measured molar yield of glyoxal from acetylene is $70 \%$ $\pm 30 \%$ [Bohn and Zetzsch, 1998]; we assume a yield of $63 \%$ following MCMv3.1. The resulting glyoxal production is $8.9 \mathrm{Tg} \mathrm{a}^{-1}$, which is $20 \%$ of the total glyoxal source. Because of its long lifetime, acetylene provides a free tropospheric source of glyoxal and hence of SOA.

[23] Aromatics are mainly emitted by combustion and solvent use. Chamber studies show that they produce glyoxal and methylglyoxal during the first stage of $\mathrm{OH}$ oxidation as a result of ring-cleavage [Volkamer et al., 2001]. We averaged the measured dicarbonyl molar yields reported in literature: $0.25 \pm 0.086$ glyoxal for benzene, $0.16 \pm 0.10$ glyoxal and $0.12 \pm 0.05$ methylglyoxal for toluene, and $0.16 \pm 0.12$ glyoxal and $0.23 \pm 0.11$ methylglyoxal for xylene [Tuazon et al., 1986; Atkinson, 1990; Yu et al., 1997; Bethel et al., 2000; Volkamer et al., 2001; Atkinson and Avery, 2003; Zhao et al., 2005; Berndt and Böge, 2006]. Benzene and toluene, with lifetimes exceeding days, enhance the dicarbonyl concentrations in the outflow of anthropogenic emission regions.

[24] Direct biofuel and biomass burning emissions of glyoxal, methylglyoxal, and their intermediate precursors glycolaldehyde and hydroxyacetone have been reported in 
several studies [McDonald et al., 2000; Hays et al., 2002; Christian et al., 2003; Greenberg et al., 2006]. We use emission ratios relative to $\mathrm{CO}$ from the literature (Table 1). The corresponding dicarbonyl sources from the direct emissions of glycolaldehyde and hydroxyacetone are relatively small, but the direct emissions of glyoxal and methylglyoxal represent a significant contribution to their global budgets (Table 1).

[25] In addition to gas phase production, hydrates of glyoxal and methylglyoxal may also be produced in the aqueous phase. Model studies by Lim et al. [2005] and Warneck [2005] suggest that aqueous-phase oxidation of glycolaldehyde hydrates and other hydroxy and hydroperoxy aldehydes can be major sources of glyoxal hydrate and methylglyoxal hydrate in cloud water. However, since we assume that the uptake of dicarbonyls in the aqueous phase is irreversible, this aqueous production does not contribute to the gas-phase dicarbonyl budgets and we neglect it here. It could however serve as an additional SOA formation pathway [Lim et al., 2005].

[26] Table 1 summarizes our global budgets for glyoxal and methylglyoxal. The global source of glyoxal is $45 \mathrm{Tg}$ $\mathrm{a}^{-1}$, including $55 \%$ from biogenic precursors, $20 \%$ from open biomass burning, $17 \%$ from biofuel use, and $8 \%$ from other anthropogenic emissions. The global source of methylglyoxal is $140 \mathrm{Tg} \mathrm{a}^{-1}$, including $87 \%$ from biogenic precursors, $5 \%$ from open biomass burning, $3 \%$ from biofuel use, and 5\% from other anthropogenic emissions. In terms of their potential as SOA sources in the free troposphere, $23 \%$ of glyoxal and $15 \%$ of methylglyoxal are produced by precursors with lifetimes longer than two days, and these precursors are principally anthropogenic for glyoxal and biogenic for methylglyoxal. There is significant uncertainty attached to all the terms in Table 1, as is apparent from the discussion above. The most important uncertainty is likely the global emission of isoprene, as current estimates range from 280 to $850 \mathrm{Tg} \mathrm{a}^{-1}$ [Wiedinmyer et al., 2004], resulting in a global source uncertainty of roughly $50 \%$ for both dicarbonyls. On the basis of a larger global isoprene emission of $500 \mathrm{Tg} \mathrm{a}^{-1}$, Myriokefalitakis et al. [2008] estimated $56 \mathrm{Tg} \mathrm{a}^{-1}$ production of glyoxal, in proportional agreement with our analysis.

\section{Sinks of Glyoxal and Methylglyoxal}

[27] Glyoxal and methylglyoxal are removed from the atmosphere by photolysis, oxidation, dry and wet deposition, and irreversible uptake by aerosols and cloud droplets. Table 2 gives the global burdens of the dicarbonyls in GEOS-Chem and the strengths of each sink. We calculate photolysis frequencies with the Fast-J algorithm [Wild et al., 2000] and absorption cross-sections and quantum yields from JPL [2006]. Glyoxal has an absorption band at 220$350 \mathrm{~nm}$ and a stronger and highly structured band above $360 \mathrm{~nm}$ with a maximum at $455 \mathrm{~nm}$. Tadić et al. [2006] found the quantum yield to be independent of pressure between 275 and $380 \mathrm{~nm}$, but it shows a Stern-Volmer dependence, i.e., inversely proportional to pressure, between 390 and $470 \mathrm{~nm}$. JPL [2006] reported quantum yields up to $445 \mathrm{~nm}$ only with no recommendation for pressure dependence. We assume a constant quantum yield of 0.021 above $445 \mathrm{~nm}$, resulting in an effective quantum
Table 2. Global Atmospheric Burdens and Sinks of Glyoxal and Methylglyoxal $^{\text {a }}$

\begin{tabular}{lcc}
\hline & Glyoxal & Methylglyoxal \\
\hline Burden, Gg & $\mathbf{1 5}$ & $\mathbf{2 5}$ \\
Lifetime, h $^{-\mathbf{1 5}}$ & $\mathbf{2 . 9}$ & $\mathbf{1 . 6}$ \\
Sinks, Tg a $^{-1}$ & & \\
Photolysis $_{\text {Oxidation by OH }^{\mathrm{b}}}$ & 28 & 100 \\
Secondary organic aerosol formation $^{\mathrm{c}}$ & 6.5 & 15 \\
Dry deposition $^{\text {Wet deposition }}$ & $6.4^{\mathrm{d}}$ & $16^{\mathrm{e}}$ \\
Total & 2.2 & 1.7 \\
\hline
\end{tabular}

${ }^{\mathrm{a}}$ Global annual mean values from the GEOS-Chem simulation.

${ }^{\mathrm{b}}$ Oxidation by $\mathrm{NO}_{3}$ is negligibly small $\left(<0.1 \mathrm{Tg} \mathrm{a}^{-1}\right)$.

${ }^{\mathrm{c}}$ From uptake by aqueous particles and cloud droplets followed by oxidation and/or oligomerization.

${ }^{\mathrm{d}}$ Includes $5.5 \mathrm{Tg} \mathrm{a}^{-1}$ in clouds and $0.95 \mathrm{Tg} \mathrm{a}^{-1}$ in aqueous aerosols.

e Includes $14 \mathrm{Tg} \mathrm{a}^{-1}$ in clouds and $1.4 \mathrm{Tg} \mathrm{a}^{-1}$ in aqueous aerosols.

yield of 0.035 averaged over the solar spectrum at sea level that matches the measured values of $0.029-0.035$ for that quantity [Plum et al., 1983; Volkamer et al., 2005a; Tadić et al., 2006]. The $220-350 \mathrm{~nm}$ absorption band is responsible globally for $40 \%$ of the photolysis and the band above 360 $\mathrm{nm}$ for $60 \%$. Our calculated glyoxal lifetime for clear-sky conditions at noon in Mexico City in April is $1.5 \mathrm{~h}$, in good agreement with the $1.3 \mathrm{~h}$ measured by Volkamer et al. [2005b]. The global glyoxal lifetime against photolysis is $4.9 \mathrm{~h}$.

[28] Methylglyoxal also has two relevant absorption bands: a continuum band between 225 and $335 \mathrm{~nm}$ and a slightly stronger and more structured band between 335 and $475 \mathrm{~nm}[J P L, 2006]$. The quantum yield is unity and independent of pressure between 290 and $370 \mathrm{~nm}$, but it shows a Stern-Volmer dependence above $380 \mathrm{~nm}[J P L$, 2006]. The quantum yield of methylglyoxal above $440 \mathrm{~nm}$ has not been reported. We assume it here to be zero since our resulting effective quantum yield of 0.14 agrees with the measured value of $0.107 \pm 0.030$ by Plum et al. [1983]. Each of the two absorption bands is responsible for roughly half of the photolysis. The global methylglyoxal lifetime against photolysis is $2.2 \mathrm{~h}$.

[29] The only significant tropospheric oxidants of glyoxal and methylglyoxal in the gas phase are thought to be $\mathrm{OH}$ and $\mathrm{NO}_{3}$ [MCMv3.1]. The rate constants for oxidation of glyoxal by $\mathrm{OH}$ and $\mathrm{NO}_{3}$ are $1.15 \times 10^{-11}$ molecules $\mathrm{cm}^{-3} \mathrm{~s}^{-1}[J P L, 2006]$ and $1.44 \times 10^{-12}$ $\exp (-1862 / T)$ molecules $\mathrm{cm}^{-3} \mathrm{~s}^{-1}$ (MCMv3.1), respectively. The rate constants for oxidation of methylglyoxal by $\mathrm{OH}$ and $\mathrm{NO}_{3}$ are $1.5 \times 10^{-11}$ [IUPAC, 2006] and $3.46 \times 10^{-12} \exp (-1862 / T)$ [MCMv3.1], respectively. For both dicarbonyls, OH accounts for $99 \%$ of the gas phase oxidation; the resulting oxidation lifetimes are $20 \mathrm{~h}$ for glyoxal and $15 \mathrm{~h}$ for methylglyoxal.

[30] Glyoxal and methylglyoxal are removed by dry and wet deposition on account of their high water solubility including hydrolysis, characterized by the effective Henry's Law constant $\left(H^{*}\right)$. For glyoxal we use $H_{298 \mathrm{~K}}^{*}=3.6 \times 10^{5}$ $\mathrm{M} \mathrm{atm}{ }^{-1}$ [Zhou and Mopper, 1990b] and assume the temperature dependence of formaldehyde $H^{*}=H_{298 \mathrm{~K}}^{*}$ $\exp \left[7.2 \times 10^{3} \times(1 / T-1 / 298)\right]$ following Schweitzer et al. [1998]. For methylglyoxal, we use $H_{298 \mathrm{~K}}^{*}=3.7 \times 10^{3} \mathrm{M}$ $\mathrm{atm}^{-1}$ and $H^{*}=H_{298 \mathrm{~K}}^{*} \exp \left[7.5 \times 10^{3} \times(1 / T-1 / 298)\right]$ as measured by Betterton and Hoffmann [1988]. We assume 

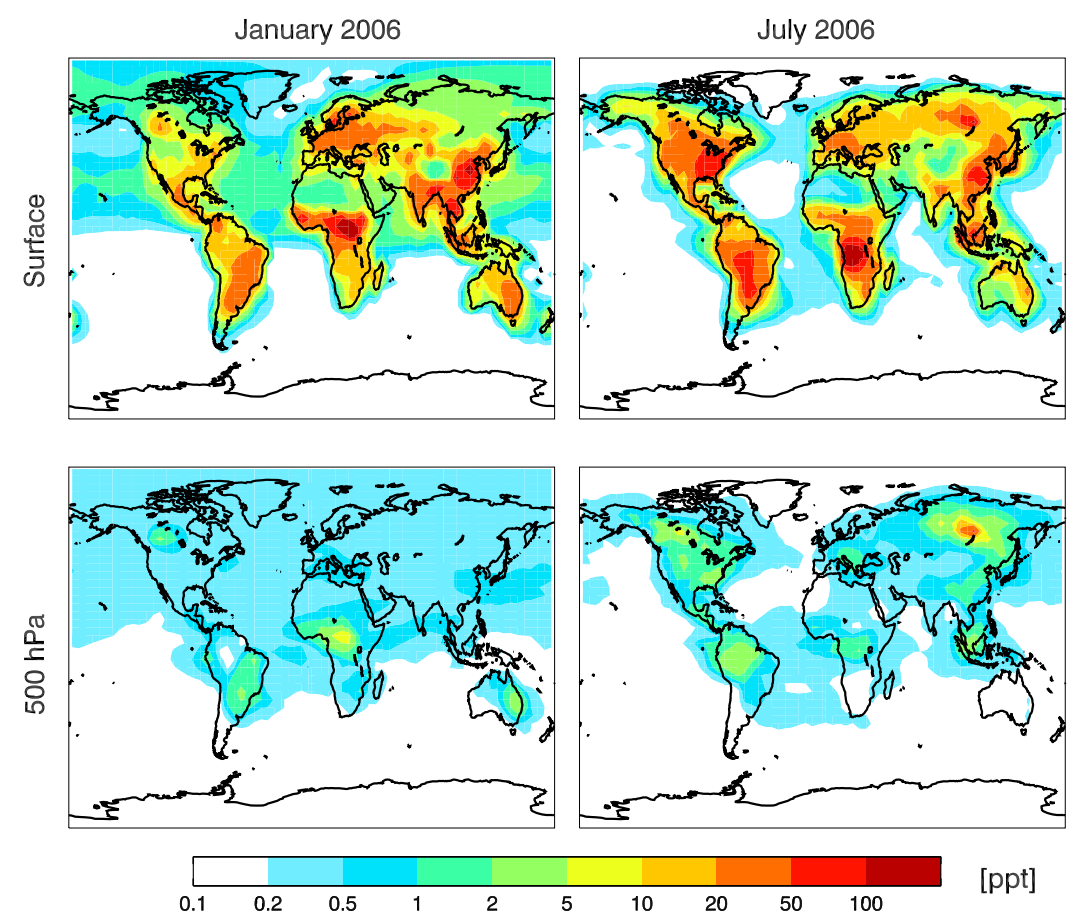

Figure 2a. Simulated daytime (9-15 LT) concentrations of glyoxal in surface air and at $500 \mathrm{hPa}$ for January and July 2006.

that glyoxal and methylglyoxal are not deposited on ice particles nor retained by the ice crystals when cloud droplets freeze. Deposition is only a minor sink for both dicarbonyls (Table 2).

[31] We assume in the model irreversible uptake of both glyoxal and methylglyoxal by aqueous particles following the work of Liggio et al. [2005b] for glyoxal and Zhao et al. [2006] for methylglyoxal. The reactive uptake coefficient, $\gamma$, represents the probability that a collision between a gas molecule and the aqueous particle surface will result in uptake. Measured $\gamma$ values for glyoxal on aqueous particles range from $10^{-3}$ to $10^{-2}$ [Schweitzer et al., 1998; Liggio et al., 2005a, 2005b]. Liggio et al. [2005b] found little variation in $\gamma$ over a broad range of aqueous particle composition, but found very low $\gamma$ for solid particles. Zhao et al. [2006] measured the irreversible uptake of methylglyoxal by bulk $\mathrm{H}_{2} \mathrm{SO}_{4}$-water solutions and found a value $\gamma=7.6 \times 10^{-3}$ at $58 \mathrm{wt} \% \mathrm{H}_{2} \mathrm{SO}_{4}$, decreasing with increasing acidity. We adopt here the median value of $\gamma=2.9 \times 10^{-3}$ for glyoxal from Liggio et al. [2005b] and assume the same value for methylglyoxal.

[32] Aerosol types in GEOS-Chem include sulfate, nitrate, dust, sea salt, elemental carbon, and organic carbon [Alexander et al., 2005; Park et al., 2006; Fairlie et al., 2007; Liao et al., 2007]. Application of $\gamma$ to compute gas uptake by aqueous aerosol in the model is done as described by Martin et al. [2003]. Aerosol surface area is calculated using relative humidity-dependent effective radii. Uptake by cloud droplets takes place similarly, accounting for diffusion limitation [Jacob, 2000]. Cloud droplet surface area is calculated from the local GEOS-Chem liquid water content in the cloudy fraction of the gridbox [Park et al., 2004] by assuming effective droplet radii of $10 \mu \mathrm{m}$ for maritime clouds and $6 \mu \mathrm{m}$ for continental clouds. No reactive uptake occurs on ice particles. The resulting global mean lifetime of glyoxal against uptake and SOA formation is $20 \mathrm{~h}$, with $85 \%$ of the uptake taking place in clouds and $15 \%$ by aqueous aerosols. The corresponding lifetime for methylglyoxal is $17 \mathrm{~h}$, with $91 \%$ of the uptake taking place in clouds and $9 \%$ by aqueous aerosols.

[33] Table 2 summarizes the global sinks of glyoxal and methylglyoxal. The global atmospheric glyoxal burden is $15 \mathrm{Gg}$ and its mean lifetime is $2.9 \mathrm{~h}$, in good agreement with the burden $(20 \mathrm{Gg})$ and lifetime $(3 \mathrm{~h})$ estimates by Myriokefalitakis et al. [2008]. For methylglyoxal the burden is $25 \mathrm{Gg}$ and the mean lifetime is $1.6 \mathrm{~h}$. Although methylglyoxal has a shorter lifetime, its average concentration is higher than glyoxal, owing to the large production from isoprene and acetone. The dominant sink for both dicarbonyls is photolysis, followed by comparable sinks from oxidation and SOA formation. Deposition is negligibly small on a global scale though it would deplete the dicarbonyls from the surface layer at night. We see from Table 2 that SOA formation is only a minor sink for the dicarbonyls; thus the SOA source is not only limited by the supply of the dicarbonyls but also depends on competition from photolysis and oxidation. The largest sources of uncertainty in the model computation of dicarbonyl lifetimes are the quantum yields for photolysis, though the atmospheric measurements of effective quantum yields offer useful constraints as described above.

\section{Atmospheric Concentrations of Glyoxal and Methylglyoxal}

\subsection{Simulated Global Distributions}

[34] Figure 2a shows the simulated global distribution of glyoxal concentrations, averaged over 9-15 local time (LT), 

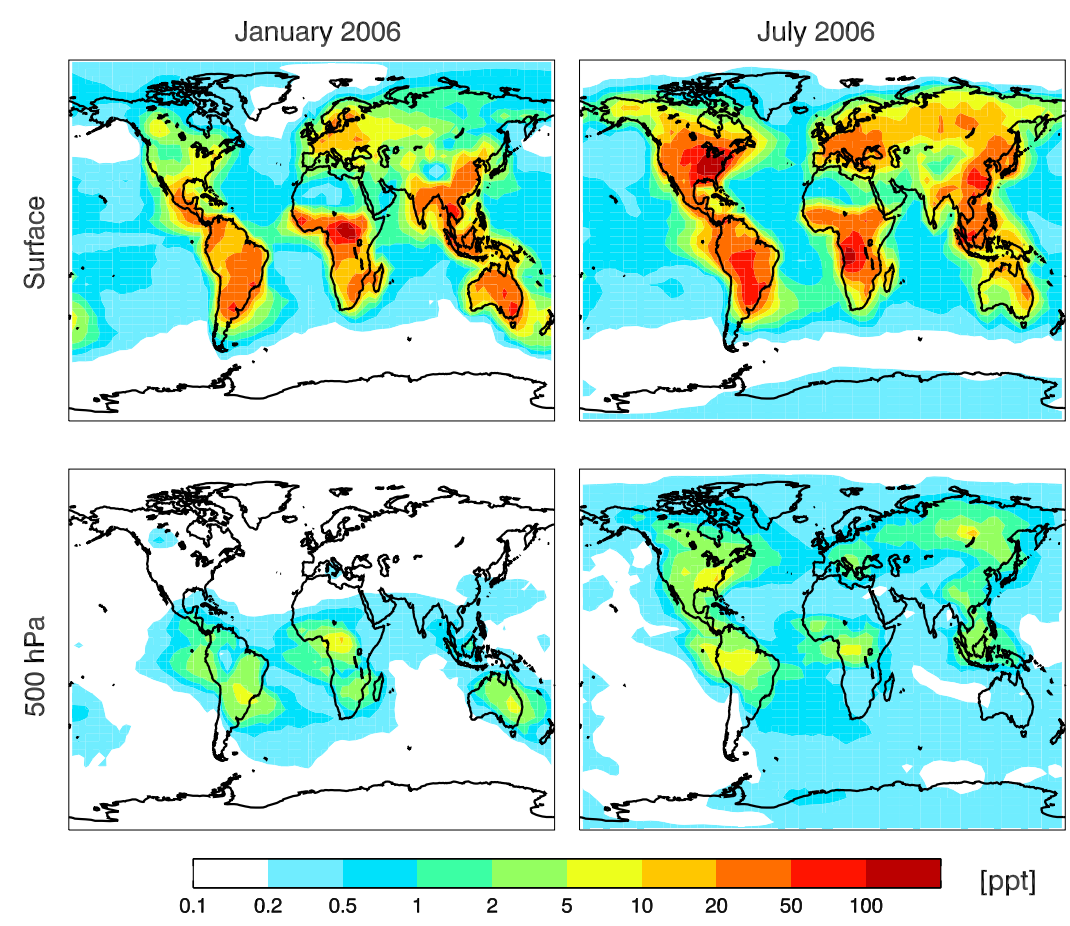

Figure 2b. Simulated daytime (9-15 LT) concentrations of methylglyoxal in surface air and at $500 \mathrm{hPa}$ for January and July 2006.

at the surface and at $500 \mathrm{hPa}$ in January and July. Surface concentrations are highest (20-100 ppt) in biomass burning and isoprene-rich regions. The anthropogenic contribution is highest in winter when the glyoxal lifetime is longest, resulting in 10-100 ppt over polluted regions of North America, Europe, and Asia. A wintertime background of $0.2-2$ ppt is present throughout the northern hemisphere due to acetylene. At $500 \mathrm{hPa}$, glyoxal concentrations exceed $1 \mathrm{ppt}$ above continental source regions.

[35] Figure 2b shows the global distribution for methylglyoxal, similarly featuring enhancements over biomass burning and vegetated regions. Daytime concentrations in summer over North America are in the 20-200 ppt range, slightly higher than glyoxal because of the larger production from isoprene. The anthropogenic source from isoalkanes maintains wintertime concentrations of $5-20 \mathrm{ppt}$ over source regions. Acetone maintains a $0.2-1 \mathrm{ppt}$ background in both hemispheres. Overall, methylglyoxal shows a stronger biogenic pattern than glyoxal.

\subsection{Comparison with Observations}

[36] Table 3 compiles the in situ nonurban dicarbonyl measurements reported in the literature and compares them with our model values sampled for the corresponding location and month. Figure 3 visualizes the comparisons. Urban and suburban glyoxal and methylglyoxal concentrations can exceed $1 \mathrm{ppb}$ due to emissions of very short-lived anthropogenic precursors [Grosjean et al., 1996, 2002; Ho and Yu, 2002a, 2002b; Volkamer et al., 2005b; Liu et al., 2006; Possanzini et al., 2007], but such local enhancements would not be resolved by our global model. No in situ observations are available to our knowledge for the southern hemisphere or for biomass burning regions.

[37] All continental measurements in Table 3 were made in rural vegetated locations at northern midlatitude in summer or early fall. Typical mean concentrations are between 10 and $100 \mathrm{ppt}$ for both dicarbonyls. Methylglyoxal concentrations are generally slightly higher than those of glyoxal except at Mt. Lassen, California [Seaman et al., 2006] and Pinnacles, Virginia [Munger et al., 1995]. Our simulated continental dicarbonyl concentrations are similarly of the order of $10-100 \mathrm{ppt}$, with methylglyoxal being slightly higher.

[38] Our model identifies photochemical oxidation of isoprene as the dominant source of glyoxal and methylglyoxal for the land sites in Table 3 . This is consistent with the strong correlations observed with isoprene [Ieda et al., 2006], methyl vinyl ketone and methacrolein [Cerqueira et al., 2003], and formaldehyde [Lee et al., 1995]. A box model analysis by Munger et al. [1995] for their eastern U.S. observations also indicates isoprene to be the major source. Evidence of anthropogenic influence in the observations appears to be limited to urban plumes [Spaulding et al., 2003; Müller et al., 2005]. No sites offer information on seasonal variation. Lee et al. [1995] measured fivefold higher dicarbonyl concentrations at a Georgia site in June 1991 than in July-August 1992. They attributed this to higher $\mathrm{NO}_{\mathrm{x}}$ concentrations and weaker UV flux for the June conditions.

[39] It appears from Figure 3 that there is no large systematic bias in the model compared to the measurements at the land sites. Figure 3 shows substantial variability in the observations that is not resolved by the model. It is not obvious from inspection of the individual data sets what is driving this variability, but local isoprene emission could be a major factor. It must also be recognized that atmospheric dicarbonyl measurements are difficult, that different studies have used different methods (Table 3), and that no intercomparison between methods has been conducted so far. 


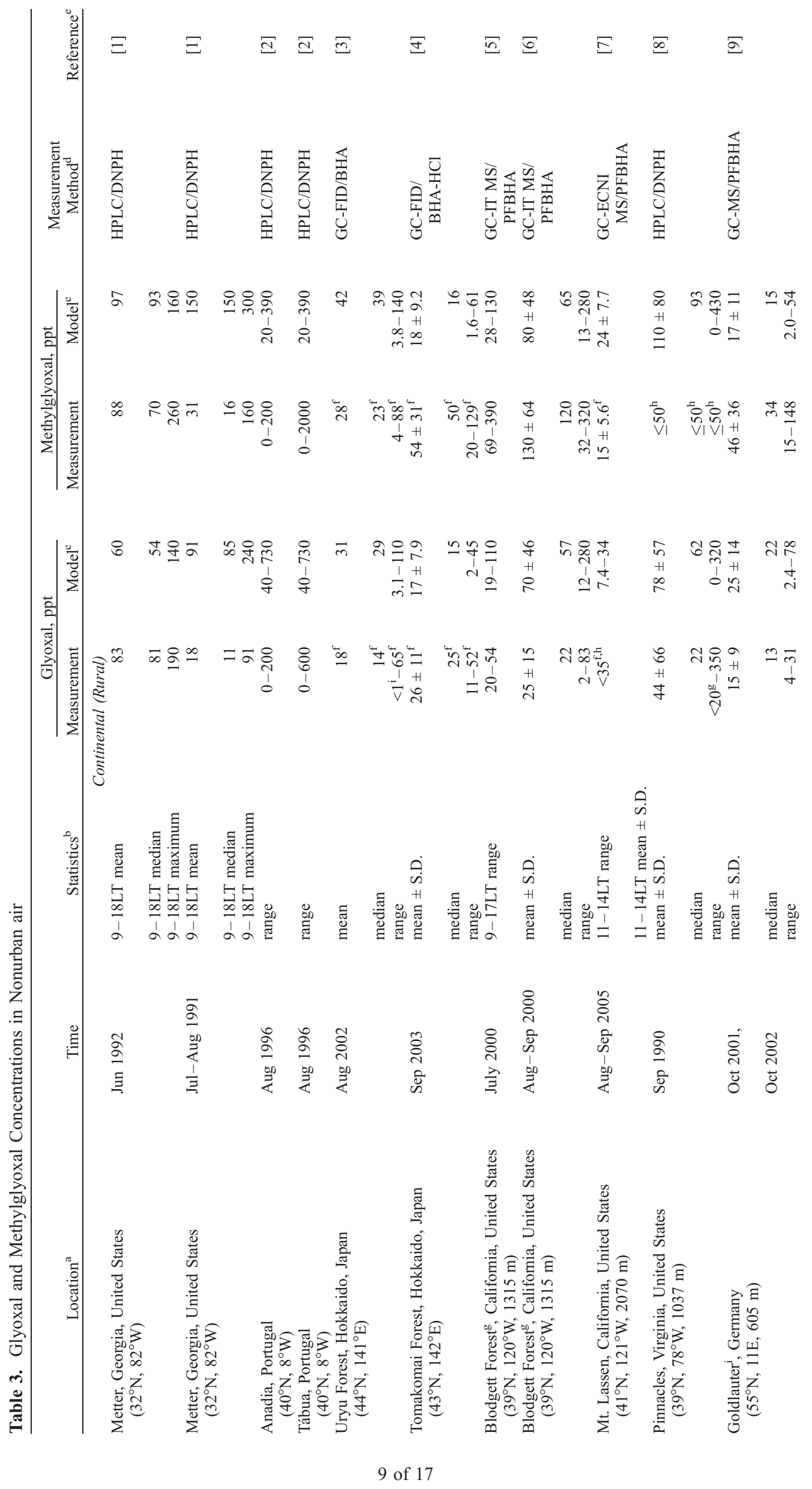




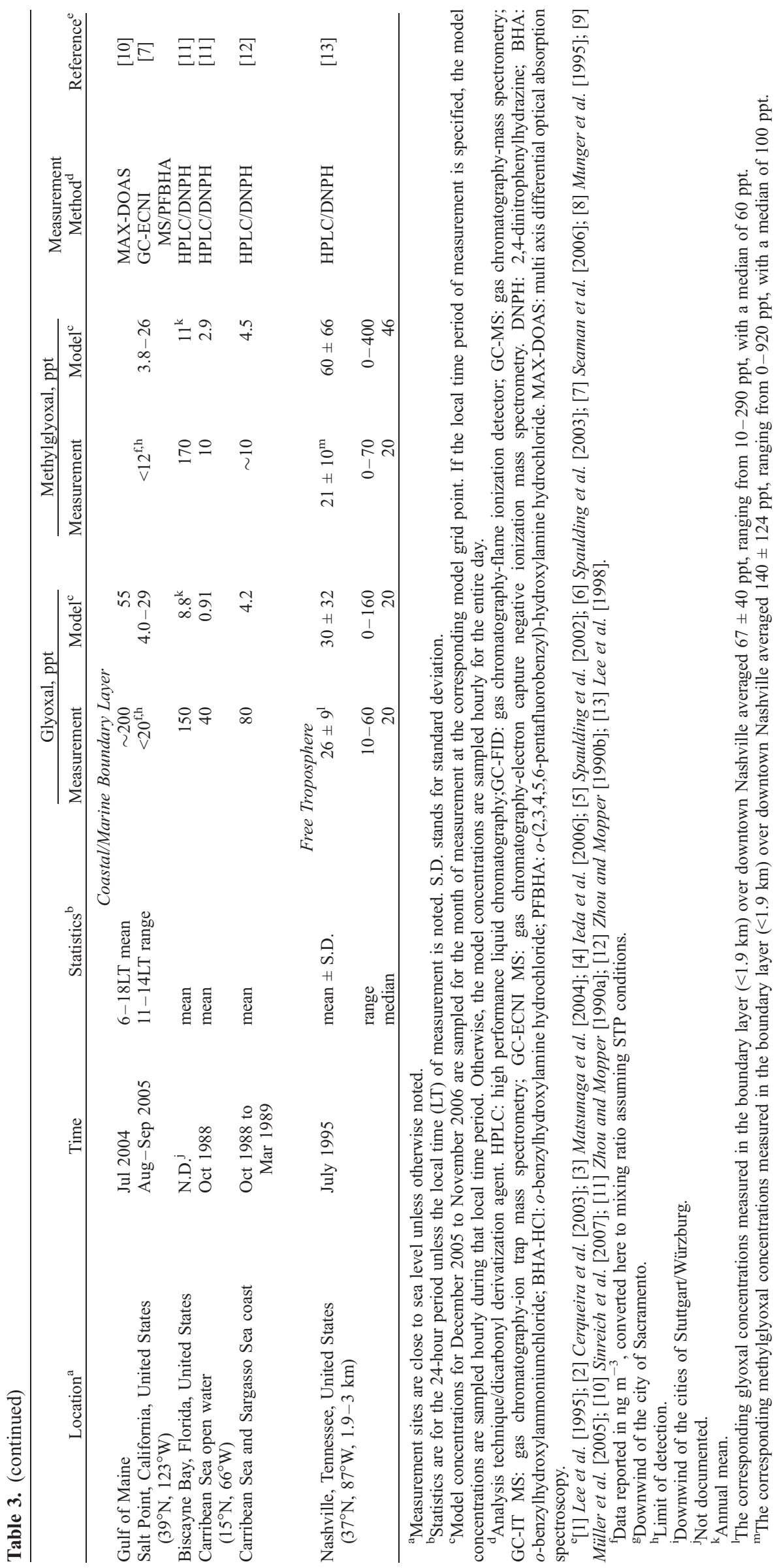

10 of 17 

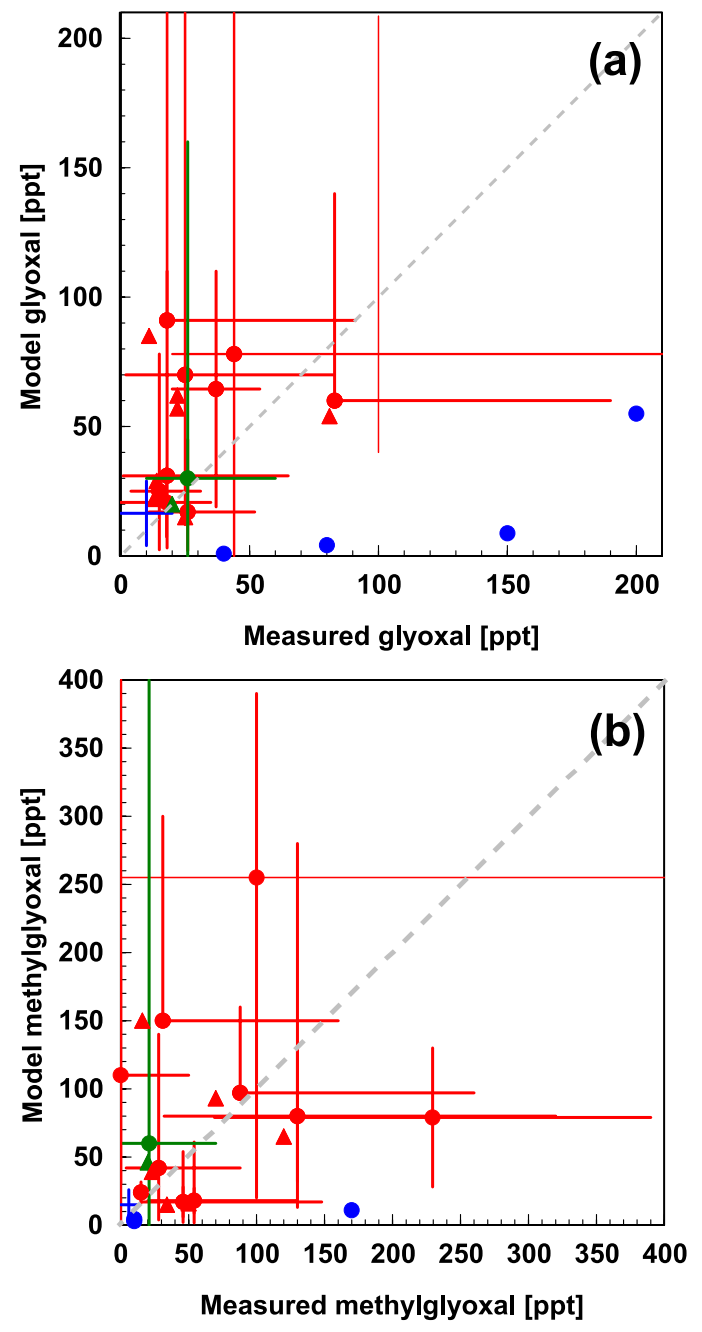

Figure 3. Scatterplots of simulated versus measured dicarbonyl concentrations from Table 3 for (a) glyoxal and (b) methylglyoxal. Locations of the in situ measurements are color coded: rural continental (red), coastal or marine boundary layer (blue), and free troposphere (green). Values are means (solid circle) or medians (solid triangle). Lines indicate ranges. Also shown is the 1:1 line (grey dashed).

[40] The only aircraft observations outside of pollution plumes available to our knowledge are those of Lee et al. [1998] up to $3 \mathrm{~km}$ over Nashville, Tennessee in summer. The measured mean glyoxal and methylglyoxal concentrations in the boundary layer were 67 and $140 \mathrm{ppt}$, respectively (not shown in Table 3). Above the boundary layer, the glyoxal and methylglyoxal concentrations decreased sharply to 26 and $21 \mathrm{ppt}$; mean model concentrations are consistent for glyoxal and a factor of 3 higher for methylglyoxal (Table 3).

[41] The five available in situ measurements of dicarbonyl concentrations in the marine boundary layer do not show a consistent picture (Table 3 and Figure 3). Measured dicarbonyl levels by Seaman et al. [2006] at a California coastal site did not exceed the detection limit of $20 \mathrm{ppt}$, consistent with the model. However, Zhou and Mopper [1990a, 1990b] found dicarbonyl concentrations in the range $10-170 \mathrm{ppt}$ off the Florida coast and in the Caribbean, comparable to typical continental concentrations although decreasing with distance from the coast. These measurements are over an order of magnitude higher than the model. Sinreich et al. [2007] also reported 100-300 ppt of glyoxal off the New England coast in summer. Such high dicarbonyl concentrations in the marine boundary layer imply either an unidentified long-lived or secondary continental source or an unidentified marine source. Dicarbonyls in marine air are discussed further below.

[42] Solar backscatter measurements of the global glyoxal column distribution from the SCIAMACHY satellite instrument have recently been reported [Wittrock et al., 2006]. For cloud free scenes the accuracy of glyoxal vertical column retrieved from SCIAMACHY measurements depends mainly on (1) the fitting accuracy, (2) the surface spectral reflectance, (3) the assumption for the aerosol vertical distribution and its optical thickness, and (4) the assumed vertical distribution of glyoxal in the lowermost troposphere. The uncertainty of the glyoxal vertical column $\left(\mathrm{VC}_{\text {glyoxal }}\right)$ at a given location $\left(60 \times 30 \mathrm{~km}^{2}\right.$ footprint $)$ for the monthly composite of cloud free scenes (cloud fraction $<20 \%$ ) is given by

$$
x \times \mathrm{VC}_{\text {glyoxal }}+2 \times 10^{14} \text { molecules } \mathrm{cm}^{-2}
$$

The value of $x$ is strongly scene-dependent but varies typically in the range 0.1 to 0.3 . The second term is determined by the minimum detectable absorption of glyoxal assuming nonsystematic errors only. A detailed discussion including possible systematic error sources is presented elsewhere [Wittrock et al., 2006; Wittrock, 2006].

[43] Figure 4 shows the monthly mean glyoxal column concentrations observed by SCIAMACHY for January and July 2006. The highest values are over the biomass burning locations of Siberia, Africa, South America, and Indonesia, exceeding $4 \times 10^{14}$ molecules $\mathrm{cm}^{-2}$. Concentrations also generally exceed $3 \times 10^{14}$ molecules $\mathrm{cm}^{-2}$ over tropical forests outside of the biomass burning season and this may be due to isoprene emission. Concentrations over eastern China and northern India in July are $3-5 \times 10^{14}$ molecules $\mathrm{cm}^{-2}$, reflecting local biogenic and biomass burning emissions. Moderate levels of $2-3.5 \times 10^{14}$ molecules $\mathrm{cm}^{-2}$ are observed over the southeastern U.S and Europe in July, consistent with a biogenic source. There are elongated regions of glyoxal concentrations exceeding $3 \times 10^{14}$ molecules $\mathrm{cm}^{-2}$ over the tropical oceans which Wittrock et al. [2006] attributed at least partly to marine precursors.

[44] Model glyoxal columns also shown in Figure 4 are similar in pattern to that retrieved from SCIAMACHY observations over land except in eastern China and northern India in July, where biogenic and biomass burning VOC emissions are low in the model inventory [Fu et al., 2007]. The model does not show the high glyoxal concentrations over the tropical oceans observed by SCIAMACHY, and we previously pointed out the model underestimate of in situ observations in marine air (Table 3). Assuming a wellmixed marine boundary layer of $1.5 \mathrm{~km}$, the $3 \times 10^{14}$ molecules $\mathrm{cm}^{-2}$ glyoxal column observed by SCIAMACHY over the tropical oceans roughly translates to $100 \mathrm{ppt}$, comparable to the in situ measurements by Zhou 


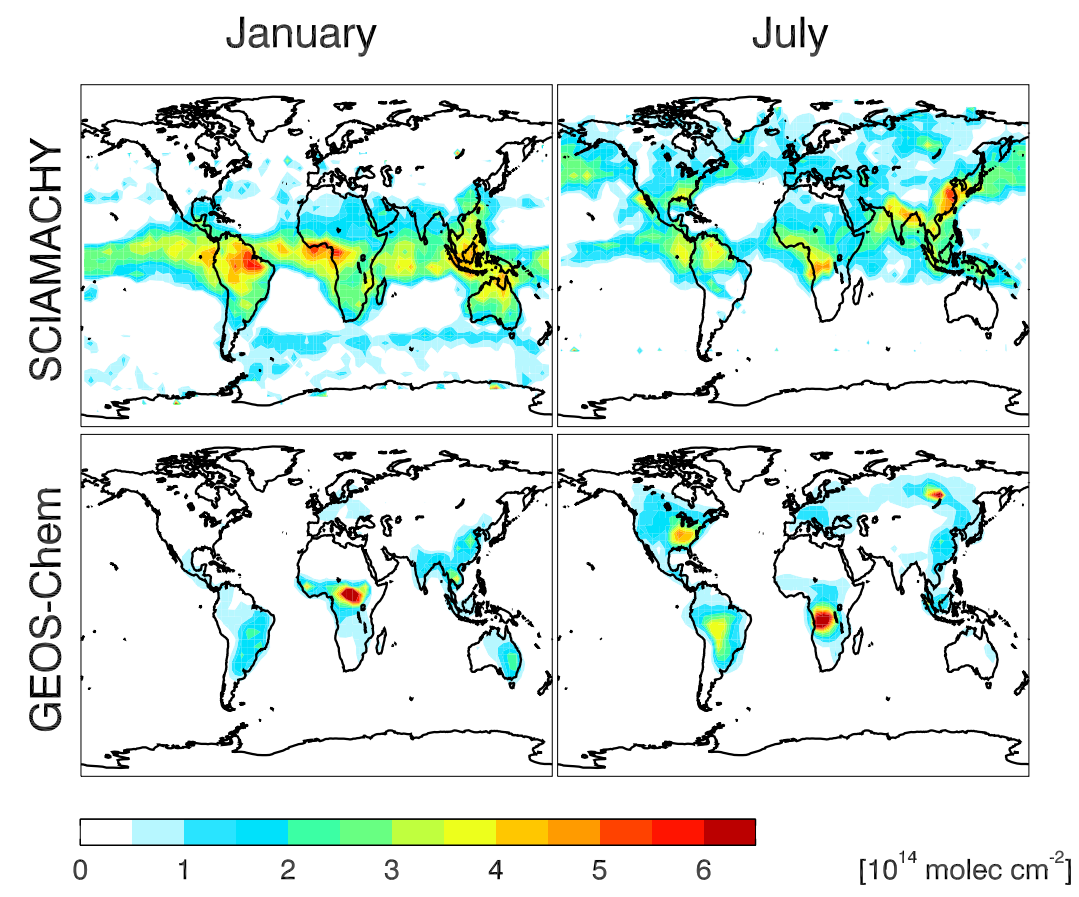

Figure 4. Monthly mean glyoxal vertical column concentrations for January and July 2006. Top: SCIAMACHY observations at 10 LT. Bottom: GEOS-Chem model results sampled daily at 9-12LT.

and Mopper [1990a, 1990b] and Sinreich et al. [2007]. We conducted model sensitivity tests lengthening the induction time for dicarbonyl formation from isoprene oxidation, and find that the general pattern of continental outflow as simulated by the model does not match the geographical distribution of elevated glyoxal observed by SCIAMACHY over the tropical oceans. This would imply a marine source for the observed glyoxal. Given a typical glyoxal lifetime of $1 \mathrm{~h}$ in the tropics, the SCIAMACHY observations of $3 \times$ $10^{14}$ molecules $\mathrm{cm}^{-2}$ over the tropical oceans imply a marine source of $8 \times 10^{10}$ molecules $\mathrm{cm}^{-2} \mathrm{~s}^{-1}$. This is at least an order of magnitude higher than measured marine emissions of nonmethane hydrocarbons [Plass-Dülmer et al., 1995; Broadgate et al., 1997; Liakakou et al., 2007]. Measured glyoxal concentrations in surface seawater peak in the late afternoon, hinting at a marine photochemical source, possibly involving the decomposition of dissolved organic matter [Mopper and Stahovec, 1986; Zhou and Mopper, 1997]. The spatial distribution of the enhanced marine glyoxal observed by SCIAMACHY matches closely that of ocean chlorophyll (e.g., MODIS Aqua Level 3 Chlorophyll, available at http://oceancolor.gsfc.nasa.gov/ PRODUCTS/L3_chlo.html]. The origin of the high glyoxal concentration apparent in the marine boundary layer observations warrants further investigation.

\section{Implications for Secondary Organic Aerosol Formation}

[45] Our global simulation of glyoxal and methylglyoxal allows an estimate of the SOA production from irreversible uptake of these dicarbonyls by clouds and aqueous aerosols. Table 4 compares the global source and burden of this dicarbonyl SOA to those simulated in GEOS-Chem from the standard mechanism involving reversible partitioning of oxidation products of biogenic VOCs and aromatics [Chung and Seinfeld, 2002; Liao et al., 2007; Henze and Seinfeld, 2006; Henze et al., 2008]. It is not clear whether or not the

Table 4. Global Sources of Secondary Organic Aerosol in GEOS-Chem ${ }^{\mathrm{a}}$

\begin{tabular}{|c|c|c|c|c|c|}
\hline Mechanism & Reversible & Reversible & Reversible & Irreversible & \\
\hline Precursors & Terpenes, Terpenoid Alcohols, and Sesquiterpenes & Isoprene & Aromatics $^{b}$ & Glyoxal and Methylglyoxal & Total \\
\hline Source, $\mathrm{Tg} \mathrm{C} \mathrm{a}$ & 9.0 & 6.7 & 1.7 & $11^{\mathrm{c}}$ & 29 \\
\hline Above $1.5 \mathrm{~km}$ & 3.1 & 2.8 & 0.95 & 4.4 & \\
\hline Below $1.5 \mathrm{~km}$ & 5.9 & 3.9 & 0.72 & 6.2 & \\
\hline Annual mean burden, $\mathrm{Tg} \mathrm{C}$ & 0.19 & 0.21 & 0.04 & $0.17^{\mathrm{d}}$ & 0.62 \\
\hline Above $1.5 \mathrm{~km}$ & 0.14 & 0.18 & 0.03 & 0.12 & \\
\hline Below $1.5 \mathrm{~km}$ & 0.05 & 0.03 & 0.01 & 0.05 & \\
\hline
\end{tabular}

${ }^{a}$ Including reversible formation from condensation of semivolatile products of VOC oxidation, and irreversible formation from oxidation and/or oligomerization of glyoxal and methylglyoxal in aqueous aerosols and clouds. Global production rates of each aerosol type formed by the reversible pathway are derived from balance with deposition. The organic to carbon mass ratio for all reversible-partitioning SOA is assumed to be 2.1, following Henze et al. [2008].

${ }^{\mathrm{b}}$ From Henze et al. [2008].

c Includes 2.6 $\mathrm{Tg} \mathrm{C} \mathrm{a}^{-1}$ from glyoxal and $8 \mathrm{Tg} \mathrm{C} \mathrm{a}^{-1}$ from methylglyoxal (Table 2).

${ }^{\mathrm{d}}$ Includes $0.04 \mathrm{Tg} \mathrm{C}$ from glyoxal and $0.13 \mathrm{Tg} \mathrm{C}$ from methylglyoxal (Table 2). 
reversible and irreversible pathways should be viewed as additive, but it is useful in any case to compare their magnitudes from a consistent simulation. Estimates for the reversible SOA production from biogenic VOCs as given in Table 4 assume partitioning onto both organic and aqueous aerosols as an upper estimate following Park et al. [2006], and are therefore higher than previous model estimates using only organic aerosols as substrate [Henze and Seinfeld, 2006; Liao et al., 2007].

[46] Table 4 gives the global source of SOA from irreversible uptake of dicarbonyls as $11 \mathrm{Tg} \mathrm{C} \mathrm{a}^{-1}$, including $2.6 \mathrm{Tg}$ $\mathrm{a}^{-1}$ from glyoxal and $8 \mathrm{Tg} \mathrm{C} \mathrm{a}^{-1}$ from methylglyoxal. Relative to the reversible partitioning mechanism, this dicarbonyl SOA increases the global SOA production by $60 \%$ and SOA concentration by $40 \%$. The dicarbonyl SOA produced by isoprene alone is $7.6 \mathrm{Tg} \mathrm{Ca}^{-1}$, potentially exceeding the source of reversible SOA from isoprene. $79 \%$ of the dicarbonyl SOA in the model is biogenic; biomass burning, biofuel use, and other anthropogenic emissions contribute $9 \%, 7 \%$, and $5 \%$, respectively. In the free troposphere, however, $64 \%$ of the dicarbonyl SOA is nonbiogenic. The spatial distribution of the dicarbonyl SOA (not shown) is similar to that of the gaseous dicarbonyls.

[47] The lifetime of the dicarbonyl SOA is $5.6 \mathrm{~d}$, shorter than the lifetimes of the reversibly partitioned SOA from terpenes $(7.7 \mathrm{~d})$, isoprene $(11 \mathrm{~d})$, and aromatics $(10 \mathrm{~d})$. As shown in Table 4, the dicarbonyl SOA burden in the free troposphere is less than that of the reversible SOA even though the production is larger. Reversibly partitioned SOA has longer lifetimes than dicarbonyl SOA in the free troposphere, since it can temporarily evaporate and reside in the gas phase reservoir, which is less susceptible to wet scavenging. Therefore SOA production from dicarbonyls as implemented in our model does not preferentially increase SOA concentrations in the free troposphere relative to the reversibly produced SOA. It cannot in particular reconcile model results with the very high organic aerosol concentrations observed in the free troposphere over the NW Pacific [Heald et al., 2005].

[48] The marine source of glyoxal implied by the in situ and SCIAMACHY observations, but not reproduced by the model, could lead to significant SOA production in the marine boundary layer. Heald et al. [2006a] previously pointed out that the organic carbon (OC) aerosol concentrations observed in the marine boundary layer for different regions of the world $\left(0.05-1 \mu \mathrm{g} \mathrm{m}^{-3}\right)$ are much higher than simulated in GEOS-Chem where all OC aerosol sources are continental. To correct this discrepancy, they invoked a missing OC aerosol source of $27 \mathrm{Tg} \mathrm{C} \mathrm{a}^{-1}$ from the oceans correlated with photochemical activity.

[49] Assuming a global average SOA yield of $12 \%$ (Table 2) and an SOA lifetime of $3 \mathrm{~d}$ in the boundary layer (Table 4), the glyoxal source inferred from the high glyoxal columns observed by SCIAMACHY over the tropical oceans can result in $1.5 \mu \mathrm{g} \mathrm{m}^{-3} \mathrm{SOA}$, potentially explaining the observed $\mathrm{OC}$ aerosol concentrations in the marine boundary layer.

\section{Conclusions}

[50] We constructed global budgets of atmospheric glyoxal and methylglyoxal with the goal of quantifying their potential for global secondary organic aerosol (SOA) formation. We simulated these dicarbonyls in the GEOSChem global 3-D chemical transport model including our best current knowledge of source and sink processes. We compared the simulated concentrations to the few atmospheric observations available. We then examined the consequences of irreversible reactive uptake of the dicarbonyls by aqueous aerosols and clouds, drawing from the measured uptake coefficients $(\gamma)$ for glyoxal by Liggio et al. [2005b] and the evidence for methylgloxal uptake from Zhao et al. [2006], to determine the resulting SOA source on a global scale.

[51] We find that isoprene is the largest global source for both dicarbonyls, producing $47 \%$ of glyoxal and $79 \%$ of global methylglyoxal. Acetylene, which is mostly anthropogenic and has a global mean lifetime of $18 \mathrm{~d}$, is the second largest precursor of glyoxal (20\%). Acetone, which is mostly biogenic and has a global lifetime of $22 \mathrm{~d}$, is the second largest precursor of methylglyoxal (7\%). Because of their long lifetimes, acetylene and acetone provide background dicarbonyl sources in the free troposphere. Other minor dicarbonyl precursors include monoterpenes, methylbutenol, isoalkanes, alkenes, and aromatics. Both glyoxal and methylglyoxal, as well as their intermediate precursors glycolaldehyde and hydroxyacetone, are also emitted directly from biofuel use and biomass burning, thus significantly enhancing the concentrations in biomass burning regions. Overall, the global source of glyoxal is $45 \mathrm{Tg} \mathrm{a}^{-1}$, including 55\% from biogenic precursors, $20 \%$ from biomass burning, $17 \%$ from biofuel use, and $8 \%$ from other anthropogenic emissions. The global source of methylglyoxal is $140 \mathrm{Tg} \mathrm{a}^{-1}$, including $87 \%$ from biogenic precursors, $5 \%$ from biomass burning, 3\% from biofuel use, and 5\% from other anthropogenic emissions.

[52] Glyoxal and methylglyoxal are removed from the atmosphere in the model by photolysis, oxidation by $\mathrm{OH}$ and $\mathrm{NO}_{3}$, dry and wet deposition, and irreversible uptake by aqueous aerosols and clouds to form SOA. The latter process is simulated by assuming a reactive uptake coefficient $\gamma=2.9 \times 10^{-3}$ for both glyoxal and methylglyoxal on aqueous surfaces, following the mean measured value by Liggio et al. [2005b] for glyoxal. The dominant sink for both dicarbonyls is photolysis, followed by comparable losses to oxidation and SOA formation, the latter taking place mostly in clouds. Thus the SOA formation from dicarbonyls is determined not only by the dicarbonyl source but also by competition with photolysis and oxidation. Better data are needed for the quantum yields for photolysis, although broadband measurements of the effective quantum yields weighted over the solar spectrum provide valuable constraints. Deposition of dicarbonyls is a negligible sink on a global scale though it would be expected to deplete the surface layer at night. The global burden of glyoxal in the model is $15 \mathrm{Gg}$ with a mean atmospheric lifetime of $2.9 \mathrm{~h}$. The global burden of methylglyoxal is $25 \mathrm{Gg}$ with a mean atmospheric lifetime of $1.6 \mathrm{~h}$.

[53] Simulated daytime concentrations of dicarbonyls in surface air are highest $(10-100 \mathrm{ppt})$ in biomass burning regions, in forested regions during the growing season, and in anthropogenic source regions in winter. Production from long-lived precursors, acetylene for glyoxal and acetone for 
methylglyoxal, maintains background concentrations of the order of $1 \mathrm{ppt}$ in the remote troposphere.

[54] We compared model results to the ensemble of in situ nonurban measurements of glyoxal and methylglyoxal reported in the literature. Observations at land sites are all for northern midlatitudes summer and show concentrations in the $10-100 \mathrm{ppt}$ range, with methylglyoxal generally higher than glyoxal, consistent with the model. Global observations of glyoxal columns from the SCIAMACHY satellite instrument [Wittrock et al., 2006] show similar patterns as the model over land, with highest concentrations over biomass burning regions and over the tropical forests.

[55] The SCIAMACHY data show zonally elongated regions of high glyoxal concentrations over the tropical oceans that are not reproduced by the model and cannot be simply explained by continental outflow. The model similarly underestimates by an order of magnitude the high (10$100 \mathrm{ppt}$ ) glyoxal and methylglyoxal concentrations observed from a few ship cruises [Zhou and Mopper, 1990a, 1990b; Sinreich et al., 2007]. The high values observed by SCIAMACHY are correlated with chlorophyll, suggesting a possible marine biological or photochemical source.

[56] We obtain a global source of SOA from the irreversible uptake of dicarbonyls of $11 \mathrm{Tg} \mathrm{C} \mathrm{a}^{-1}$, including $2.6 \mathrm{Tg}$ $\mathrm{C} \mathrm{a}^{-1}$ from glyoxal and $8 \mathrm{Tg} \mathrm{C} \mathrm{a}^{-1}$ from methylglyoxal. About $90 \%$ of this source is in clouds. This dicarbonyl SOA source can be compared to an SOA source of $17.5 \mathrm{Tg} \mathrm{C} \mathrm{a}^{-1}$ calculated in GEOS-Chem from the standard mechanism involving reversible partitioning of the oxidation products of biogenic VOCs (including isoprene) and aromatics. 79\% of the global dicarbonyl SOA in the model is biogenic, $9 \%$ is from biomass burning, 7\% from biofuel use, and 5\% from other anthropogenic emissions. In the free troposphere, however, $64 \%$ of the dicarbonyl SOA is anthropogenic.

[57] It thus appears that irreversible uptake of glyoxal and methylglyoxal by aqueous aerosols and clouds, followed by oligomerization or oxidation in the aqueous phase, could make a significant contribution to the global SOA pool. More work is needed to establish the viability of this mechanism in the laboratory. Important gaps in the atmospheric chemistry of glyoxal and methylglyoxal must be addressed, particularly the quantum yields for photolysis and the fate of the organic hydroperoxides $(\mathrm{ROOH})$ serving as intermediate precursors under low- $\mathrm{NO}_{\mathrm{x}}$ conditions. The possibility of an unknown marine dicarbonyl source also needs to be examined. It could possibly help to explain observations of relatively high organic aerosol concentrations in the marine boundary layer.

[58] Acknowledgments. This work was supported by the Electric Power Research Institute and by the Atmospheric Chemistry Program of the National Science Foundation. M. Vrekoussis acknowledges consecutive supporting fellowships by the A. v. Humbolt Foundation and the EU (Marie Curie - Intra European Fellowships).

\section{References}

Alexander, B., R. J. Park, D. J. Jacob, Q. B. Li, R. M. Yantosca, J. Savarino, C. C. W. Lee, and M. H. Thiemens (2005), Sulfate formation in sea-salt aerosols: Constraints from oxygen isotopes, J. Geophys. Res., 110, D10307, doi:10.1029/2004JD005659.

Altieri, K. E., A. G. Carlton, H.-J. Lim, B. J. Turpin, and S. P. Seitzinger (2006), Evidence for oligomer formation in clouds: Reactions of isoprene oxidation products, Environ. Sci. Technol., 40, 4956-4960.

Altieri, K. E., S. P. Seitzinger, A. G. Carlton, B. J. Turpin, G. C. Klein, and A. G. Marshall (2008), Oligomers formed through in-cloud methylglyoxal reactions: Chemical composition, properties, and mechanisms investigated by ultra-high resolution FT-ICR mass spectrometry, Atmos. Environ. 42(7), 1476-1490, doi:10.1016/j.atmosenv.2007.11.015.

Andreae, M. O., and P. Merlet (2001), Emission of trace gases and aerosols from biomass burning, Global Biogeochem. Cycles, 15(4), 1-12.

Atkinson, R. (1990), Gas-phase tropospheric chemistry of organic compounds: A review, Atmos. Environ., 24A(1), 1-41.

Atkinson, R. (2000), Atmospheric chemistry of VOCs and $\mathrm{NO}_{\mathrm{x}}$, Atmos. Environ., 34, 2063-2101.

Atkinson, R., and J. Arey (2003), Gas-phase tropospheric chemistry of biogenic volatile organic compounds: A review, Atmos. Environ., 37(Suppl. (2)), S197-S219, doi:10.1016/S1352-2310(03)00391-1.

Bacher, C., G. S. Tyndall, and J. J. Orlando (2001), The atmospheric chemistry of glycolaldehyde, J. Atmos. Chem., 39, 171-189.

Barsanti, K. C., and J. F. Pankow (2005), Thermodynamics of the formation of atmospheric organic particulate matter by accretion reactions. part II: Dialdehydes, methylglyoxal, and diketones, Atmos. Environ., 39, 65976607, doi:10.1016/j.atmosenv.2005.07.056.

Berndt, T., and O. Böge (2006), Formation of phenol and carbonyls from the atmospheric reaction of $\mathrm{OH}$ radicals with benzene, Phys. Chem. Chem. Phys., 8, 1205-1214, doi:10.1039/b514148f.

Bethel, H. L., R. Atkinson, and J. Arey (2000), Products of the gas-phase reactions of $\mathrm{OH}$ radicals with p-xylene and 1, 2, 3- and 1,2, 4-trimethylbenzene: Effect of $\mathrm{NO}_{2}$ concentration, J. Phys. Chem. A, 104, 89228929.

Betterton, E. A., and M. R. Hoffmann (1988), Henry's Law constants of some environmentally important aldehydes, Environ. Sci. Technol., 22, $1415-1418$.

Bey, I., D. J. Jacob, R. M. Yantosca, J. A. Logan, B. Field, A. M. Fiore, Q. Li, H. Liu, L. J. Mickley, and M. Schultz (2001), Global modeling of tropospheric chemistry with assimilated meteorology: Model description and evaluation, J. Geophys. Res., 106(D19), 23,073-23,095.

Blitz, M. A., D. E. Heard, M. J. Pilling, S. R. Arnold, and M. P. Chipperfield (2004), Pressure and temperature-dependent quantum yields for the photodissociation of acetone between 279 and $327.5 \mathrm{~nm}$, Geophys. Res. Lett., 31 , L06111, doi:10.1029/2003GL018793.

Bloss, C., et al. (2005), Development of detailed chemical mechanism (MCMv3.1) for the atmospheric oxidation of aromatic hydrocarbons, Atmos. Chem. Phys., 5, 641-664.

Bohn, B., and C. Zetzsch (1998), Formation of $\mathrm{HO}_{2}$ from $\mathrm{OH}$ and $\mathrm{C}_{2} \mathrm{H}_{2}$ in the presence of $\mathrm{O}_{2}$, J. Chem. Soc. Faraday Trans., 94(9), 1203-1210.

Broadgate, W. J., P. S. Liss, and S. A. Penkett (1997), Seasonal emissions of isoprene and other reactive hydrocarbon gases from the ocean, Geophys. Res. Lett., 24(21), 2675-2678.

Butkovskaya, N. I., N. Pouvesle, A. Kukui, Y. Mu, and G. Le Bras (2006), Mechanism of the $\mathrm{OH}$-initiated oxidation of hydroxyacetone over the temperature range 236-298 K, J. Phys. Chem. A, 110, 6833-6843, doi:10.1021/jp056345r.

Carlton, A. G., B. J. Turpin, H.-J. Lim, K. E. Altieri, and S. Seitzinger (2006), Link between isoprene and secondary organic aerosol (SOA): Pyruvic acid oxidation yields low volatility organic acids in clouds, Geophys. Res. Lett., 33, L06822, doi:10.1029/2005GL025374.

Carlton, A. G., B. J. Turpin, K. E. Altieri, S. Seitzinger, A. Reff, H.-J. Lin, and B. Ervens (2007), Atmospheric oxalic acid and SOA production from glyoxal: Results of aqueous photooxidation experiments, Atmos. Environ., 41(35), 7588-7602, doi:10.1016/j.atmosenv.2007.05.035.

Carrasco, N., J. F. Doussin, M. O'Connor, J. C. Wenger, B. PicquetVarrault, R. Durand-Jolibois, and P. Carlier (2007), Simulation chamber studies of the atmosphere oxidation of 2-methyl-3-buten-2-ol: Reaction with hydroxyl radicals and ozone under a variety of conditions, J. Atmos. Chem., 56(1), 33-55, doi:10.1007/s10874-006-9041-y.

Cerqueira, M. A., C. A. Pio, P. A. Gomes, J. S. Matos, and T. V. Nunes (2003), Volatile organic compounds in rural atmospheres of central Portugal, Sci. Total Environ., 313, 49-60, doi:10.1016/S0048-9697 (03)00250-X.

Christian, T. J., B. Kleiss, R. J. Yokelson, R. Holzinger, P. J. Crutzen, W. M. Hao, B. H. Saharjo, and D. E. Ward (2003), Comprehensive laboratory measurements of biomass-burning emissions: 1. Emissions from Indonesian, African, and other fuels, J. Geophys. Res., 108(D23), 4719, doi:10.1029/2003JD003704.

Chung, S. H., and J. H. Seinfeld (2002), Global distribution and climate forcing of carbonaceous aerosols, J. Geophys. Res., 107(D19), 4407, doi:10.1029/2001JD001397.

Crahan, K. K., D. Hegg, D. S. Covert, and H. Jonsson (2004), An exploration of aqueous oxalic acid production in the coastal marine atmosphere, Atmos. Environ., 38, 3757-3764, doi:10.1016/j.atmosenv.2004.04.009.

Denkenberger, K. A., R. C. Moffet, J. C. Holecek, T. P. Rebotier, and K. A. Prather (2007), Real-time, single-particle measurements of oligomers in aged ambient aerosol particles, Environ. Sci. Technol., 41, 5439-5446, doi:10.1021/es0703291. 
Environmental Protection Agency (2004), 1999 National emissions inventory version 3.0, Environmental Protection Agency, Washington, D.C. (available at http://www.epa.gov/ttn/chief/net/1999inventory.html)

Ervens, B., G. Feingold, G. J. Frost, and S. M. Kreidenweis (2004), A modeling study of aqueous production of dicarboxylic acids: 1 . Chemical pathways and speciated organic mass production, J. Geophys. Res., 109, D15205, doi:10.1029/2003JD004387.

Fairlie, T. D., D. J. Jacob, and R. J. Park (2007), The impact of transpacific transport of mineral dust in the United States, Atmos. Environ., 41, $1251-1266$.

Fick, J., L. Pommer, C. Nilsson, and B. Andersson (2003), Effect of OH radicals, relative humidity, and time on the composition of the products formed in the ozonolysis of $\alpha$-pinene, Atmos. Environ., 37, 4087-4096.

Fick, J., C. Nilsson, and B. Andersson (2004), Formation of oxidation products in a ventilation system, Atmos. Environ., 38, 5895-5899.

Fu, T.-M., D. J. Jacob, P. I. Palmer, K. Chance, Y. X. Wang, B. Barletta, D. R. Blake, J. C. Stanton, and M. J. Pilling (2007), Space-based formaldehyde measurements as constraints on volatile organic compound emissions in east and south Asia and implications for ozone, J. Geophys. Res., 112, D06312, doi:10.1029/2006JD007853.

Goldstein, A. H., and I. E. Galbally (2007), Known and unexplored organic constituents in the Earth's atmosphere, Environ. Sci. Technol., 41(5), $1514-1521$.

Goldstein, A. H., S. M. Fan, M. L. Goulden, J. W. Munger, and S. C. Wofsy (1996), Emissions of ethene, propene, and 1-butene by a midlatitude forest, J. Geophys. Res., 101(D4), 9149-9157.

Greenberg, J. P., H. Friedli, A. B. Guenther, D. Hanson, P. Harley, and T. Karl (2006), Volatile organic emissions from the distillation and pyrolysis of vegetation, Atmos. Chem. Phys., 6, 81-91.

Grosjean, E., D. Grosjean, M. P. Fraser, and G. R. Cass (1996), Air quality model evaluation data for organics. part II: $\mathrm{C}_{1}-\mathrm{C}_{14}$ carbonyls in Los Angeles air, Environ. Sci. Technol., 30, 2687-2703.

Grosjean, D., E. Grosjean, and L. F. R. Moreira (2002), Speciated ambient carbonyls in Rio de Janeiro, Brazil, Environ. Sci. Technol., 36(7), 13891395.

Guenther, A., et al. (1995), A global model of natural volatile organic compounds emissions, J. Geophys. Res., 100(D5), 8873-8892.

Guenther, A., T. Karl, P. Harley, C. Wiedinmyer, P. I. Palmer, and C. Geron (2006), Estimates of global terrestrial isoprene emissions using MEGAN (Model of Emissions of Gases and Aerosols from Nature), Atmos. Chem Phys., 6, 3181-3210.

Hastings, W. P., C. A. Koehler, E. L. Bailey, and D. O. de Haan (2005), Secondary organic aerosol formation by glyoxal hydration and oligomer formation: Humidity effects and equilibrium shifts during analysis, Environ. Sci. Technol., 39, 8728-8735.

Hays, M. D., C. D. Geron, K. J. Linna, N. D. Smith, and J. J. Schauer (2002), Speciation of gas-phase and fine particle emissions from burning of foliar fuels, Environ. Sci. Technol., 36(11), 2281-2295, doi:10.1021/ es0111683.

Heald, C. L., D. J. Jacob, R. J. Park, L. M. Russell, B. J. Huebert, J. H. Seinfeld, H. Liao, and R. J. Weber (2005), A large organic aerosol source in the free troposphere missing from current models, Geophys. Res. Lett., 32, L18809, doi:10.1029/2005GL023831

Heald, C. L., D. J. Jacob, R. J. Park, B. Alexander, T. D. Fairlie, R. M. Yantosca, and D. A. Chu (2006a), Transpacific transport of Asian anthropogenic aerosols and its impact on surface air quality in the United States, J. Geophys. Res., 111, D14310, doi:10.1029/2005JD006847.

Heald, C. L., et al. (2006b), Concentrations and sources of organic carbon aerosol in the free troposphere over North America, J. Geophys. Res., 111, D23S47, doi:10.1029/2006JD007705.

Henze, D. K., and J. H. Seinfield (2006), Global secondary organic aerosol from isoprene oxidation, Geophys. Res. Lett., 33, L09812, doi:10.1029/ 2006GL025976.

Henze, D. K., J. H. Seinfield, N. L. Ng, J. H. Kroll, T.-M. Fu, D. J. Jacob, and C. L. Heald (2008), Global modeling of secondary organic aerosol formation from aromatic hydrocarbons: High- vs. low-yield pathways, Atmos. Chem. Phys., 8, 2405-2420.

Ho, S. S. H., and J. Z. Yu (2002a), Concentrations of formaldehyde and other carbonyls in environments affected by incense burning, J. Environ. Monit., 4, 728-733.

Ho, S. S. H., and J. Z. Yu (2002b), Feasibility of collection and analysis of airborne carbonyls by on-sorbent derivatization and thermal desorption, Anal. Chem., 74, 1232-1240.

Horowitz, L. W., J. Liang, G. M. Gardner, and D. J. Jacob (1998), Export of reactive nitrogen from North America during summertime, J. Geophys. Res., 103(D11), 13,451-13,476.

Ieda, T., Y. Kitamori, M. Mochida, R. Hirata, T. Hirano, K. Inukai, Y. Fujinuma, and K. Kawamura (2006), Dirunal variations and vertical gradients of biogenic volatile and semi-volatile organic compounds at the Tomakomai larch forest station in Japan, Tellus, 59B, 117-186, doi:10.1111/j.1600-0889.2006.0179.x

IUPAC, et al. (2006), Evaluated kinetic and photochemical data for atmospheric chemistry: Volume II - Gas phase reactions of organic species, Atmos. Chem. Phys., 6, 3625-4055.

Jacob, D. J. (2000), Heterogeneous chemistry and tropospheric ozone, Atmos. Environ., 34, 2131-2159.

Jacob, D. J., B. D. Field, E. M. Jin, I. Bey, Q. Li, J. A. Logan, R. M. Yantosca, and H. B. Singh (2002), Atmospheric budget of acetone, J. Geophys. Res., 107(D10), 4100, doi:10.1029/2001JD000694.

Jet Propulsion Laboratory (JPL) (2006), Chemical Kinetics and Photochemical Data for Use in Atmospheric Studies, Evaluation Number 15, Jet Propulsion Laboratory, California Institute of Technology, Pasadena, California

Kalberer, M., et al. (2004), Identification of polymers as major components of atmospheric organic aerosols, Science, 303, 1659-1662.

Kanakidou, M., et al. (2005), Organic aerosol and global climate modelling: A review, Atmos. Chem. Phys., 5(4), 1053-1123.

Kleinman, L. I., et al. (2007), Aircraft observations of aerosol composition and ageing in New England and Mid-Atlantic States during the summer 2002 New England Air Quality Study field campaign, J. Geophys. Res. 112, D09310, doi:10.1029/2006JD007786.

Kroll, J. H., N. L. Ng, S. M. Murphy, V. Varutbangkul, R. C. Flagan, and J. H. Seinfeld (2005), Chamber studies of secondary organic aerosol growth by reactive uptake of simple carbonyl compounds, J. Geophys. Res., 110, D23207, doi:10.1029/2005JD006004.

Lanz, V. A., M. R. Alfarra, U. Baltensperger, B. Buchmann, C. Hueglin, and A. S. H. Prévôt (2007), Source apportionment of submicro organic aerosols at an urban site by factor analytical modelling of aerosol mass spectra, Atmos. Chem. Phys., 7, 1503-1522.

Lee, Y.-N., X. Zhou, and K. Hallock (1995), Atmospheric carbonyl compounds at a rural southeastern United States site, J. Geophys. Res., 100(D12), 25,933-25,944

Lee, Y.-N., et al. (1998), Atmospheric chemistry and distribution of formaldehyde and several multioxygenated carbonyl compounds during the 1995 Nashville/Middle Tennessee Ozone Study, J. Geophys. Res., 103(D17), 22,449-22,462.

Liakakou, E., M. Vrekoussis, B. Bonsang, M. Kanakidou, and N. Mihalopoulos (2007), Isoprene above the eastern Mediterranean: Seasonal variation and contribution to the oxidation capacity of the atmosphere, Atmos. Environ., 41, $1002-1010$.

Liao, H., D. K. Henze, J. H. Seinfeld, S. Wu, and L. J. Mickley (2007), Biogenic secondary organic aerosol over the United States: Comparison of climatological simulations with observations, J. Geophys. Res., 112, D06201, doi:10.1029/2006JD007813

Liggio, J., S.-M. Li, and R. McLaren (2005a), Heterogeneous reactions of glyoxal on particulate matter: Identification of acetals and sulfate esters, Environ. Sci. Technol., 391,532-391,541.

Liggio, J., S.-M. Li, and R. McLaren (2005b), Reactive uptake of glyoxal by particulate matter, J. Geophys. Res., 110, D10304, doi:10.1029/ 2004JD005113.

Lim, H.-J., A. G. Carlton, and B. J. Turpin (2005), Isoprene forms secondary organic aerosol through cloud processing: Model simulations, Environ. Sci. Technol., 39, 4441-4446.

Liu, H., D. J. Jacob, I. Bey, and R. M. Yantosca (2001), Constraints from ${ }^{210} \mathrm{~Pb}$ and ${ }^{7} \mathrm{Be}$ on wet deposition and transport in a global three-dimensional chemical tracer model driven by assimilated meteorological fields, J. Geophys. Res., 106(D11), 12,109-12,128.

Liu, W., J. Zhang, J. Kwon, C. Weisel, B. Turpin, L. Zhang, L. Korn, M. Morandi, T. Stock, and S. Colome (2006), Concentrations and source characteristics of airborne carbonyl compounds measured outside urban residences, J. Air Waste Manage. Assoc., 56, 1196-1204. Loeffler, K. W., C. A. Koehler, N. M. Paul, and D. O. de Haan (2006), Oligomer formation in evaporating aqueous glyoxal and methyl glyoxal solutions, Environ. Sci. Technol., 40, 6318-6323.

Magneron, I., A. Mellouki, G. Le Bras, G. K. Moortgat, A. Horowitz, and K. Wirtz (2005), Photolysis and $\mathrm{OH}$-initiated oxidation of glycolaldehyde under atmospheric conditions, J. Phys. Chem. A, 109, 4551-4561.

Mari, C., D. J. Jacob, and P. Bechtold (2000), Transport and scavenging of soluble gases in a deep convective cloud, J. Geophys. Res., 105(D17), $22,255-22,267$

Martin, R. V., D. J. Jacob, R. M. Yantosca, M. Chin, and P. Ginoux (2003), Global and regional decreases in tropospheric oxidants from photochemical effects of aerosols, J. Geophys. Res., 108(D3), 4097, doi:10.1029/ 2002JD002622.

Matsunaga, S., M. Mochida, and K. Kawamura (2004), Variation on the atmospheric concentrations of biogenic carbonyl compounds and their removal processes in the northern forest at Moshiri, Hokkaido Island in Japan, J. Geophys. Res., 109, D04302, doi:10.1029/2003JD004100. 
McDonald, J. D., B. Zielinska, E. M. Fujita, J. C. Sagebiel, J. C. Chow, and J. G. Watson (2000), Fine particle and gaseous emission rates from residential wood combustion, Environ. Sci. Technol., 34(11), 20802091, doi:10.1021/es9909632.

Mopper, K., and W. L. Stahovec (1986), Sources and sinks of low molecular weight organic carbonyl compounds in seawater, Mar. Chem., 19 , $305-321$.

Müller, K., D. van Pinxteren, A. Plewka, B. Svrcina, H. Kramberger, D. Hofmann, K. Bächmann, and H. Herrmann (2005), Aerosol characterisation at the FEBUKO upwind station Goldlauter (II): Detailed organic chemical characterisation, Atmos. Environ., 39, 4219-4231, doi:10.1016/j.atmosenv.2005.02.008.

Munger, J. W., D. J. Jacob, B. C. Daube, L. W. Horowitz, W. C. Keene, and B. G. Heikes (1995), Formaldehyde, glyoxal, and methylglyoxal in air and cloudwater at a rural mountain site in central Virginia, J. Geophys. Res., 100(D5), 9325-9333.

Myriokefalitakis, S., M. Vrekoussis, K. Tsigaridis, F. Wittrock, A. Richter, C. Brühl, R. Volkamer, J. P. Burrows, and M. Kanakidou (2008), The influence of natural and anthropogenic secondary sources on the glyoxal global distribution, Atmos. Chem. Phys. Disc., 8, 1673-1708.

Nunes, F. M. N., M. C. C. Veloso, P. A. de Pereira, and P. de Andrade (2005), Gas-phase ozonolysis of the monoterpenoids $(S)$ - $(+)$-carvone, $(R)$ - (-)-carvone, (-)-carveol, geraniol and citral, Atmos. Environ., 39, $7715-7730$

Odum, J. R., T. Hoffmann, F. Bowman, D. Collins, R. C. Flagan, and J. H. Seinfeld (1996), Gas/particle partitioning and secondary organic aerosol yields, Environ. Sci. Technol., 30, 2580-2585.

Olivier, J. G. J., A. F. Bouwman, C. W. M. Van der Maas, J. J. M. Berdowski, C. Veldt, J. P. J. Bloos, A. J. H. Visschedijk, P. Y. J. Zandveld, and J. L. Haverlag (1996), Description of EDGAR Version 2.0: A set of global emission inventories of greenhouse gases and ozone-depleting substances for all anthropogenic and most natural sources on a per country basis and on $1 \times 1$ degree grid, National Institute of Public Health and the Environment RIVM Rep. 771060002 and TNO-MEP Rep. R96/119.

Olivier, J. G. J., A. F. Bouwman, J. J. M. Berdowski, C. Veldt, J. P. J. Bloos, A. J. H. Visschedijk, C. W. M. van de Maas, and P. Y. J. Zandveld (1999), Sectoral emission inventories of greenhouse gases for 1990 on a per country basis as well as on $1 \times 1$ degree, Environ. Sci. Policy, 2, $241-264$.

Orlando, J. J., G. S. Tyndall, J.-M. Fracheboud, E. G. Estupiñan, S. Haberkorn, and A. Zimmer (1999), The rate and mechanism of the gasphase oxidation of hydroxyacetone, Atmos. Environ., 33, 1621-1629.

Palmer, P. I., D. J. Jacob, A. M. Fiore, R. V. Martin, K. Chance, and T. P. Kurosu (2003), Mapping isoprene emissions over North America using formaldehyde column observations from space, J. Geophys. Res., 108(D6), 4180, doi:10.1029/2002JD002153.

Pankow, J. F. (1994a), An absorption model of gas/particle partitioning of organic compounds in the atmosphere, Atmos. Environ., 28, 185-188.

Pankow, J. F. (1994b), An absorption model of gas/particle partitioning involved in the formation of secondary organic aerosol, Atmos. Environ., 28, 189-193.

Park, R. J., D. J. Jacob, B. D. Field, R. M. Yantosca, and M. Chin (2004), Natural and transboundary pollution influences on sulfate-nitrate-ammonium aerosols in the United States: Implications for policy, J. Geophys. Res., 109, D15204, doi:10.1029/2003JD004473.

Park, R. J., D. J. Jacob, N. Kumar, and R. M. Yantosca (2006), Regional visibility statistics in the United States: Natural and transboundary pollution influences, and implications for the Regional Haze Rule, Atmos. Environ., 40, 5405-5423, doi:10.1016/j.atmosenv.2006.04.059.

Plass-Dülmer, C., R. Koppmann, M. Ratte, and J. Rudolph (1995), Light nonmethane hydrocarbons in seawater, Global Biogeochem. Cycle, 9(1), $79-100$

Plum, C. N., E. Sanhueza, R. Atkinson, W. P. L. Carter, and J. N. Pitts Jr. (1983), OH radical rate constants and photolysis rates of $\alpha$-dicarbonyls, Environ. Sci. Technol., 17, 479-484.

Possanzini, M., G. Tagliacozzo, and A. Cecinato (2007), Ambient levels and sources of lower carbonyls at Montelibretti, Rome (Italy), Water Air Soil Pollut., 183, 447-454, doi:10.1007/s11270-007-9393-1.

Saunders, S. M., M. E. Jenkin, R. G. Derwen, and M. J. Pilling (2003), Protocol for the development of the Master Chemical Mechanism, MCM v3 (Part A): Tropospheric degradation of non-aromatic volatile organic compounds, Atmos. Chem. Phys., 3, 161-180.

Schweitzer, F., L. Magi, P. Mirabel, and C. George (1998), Uptake rate measurements of methanesulfonic acid and glyoxal by aqueous droplets, J. Phys. Chem. A, 102, 593-600.

Seaman, V. Y., M. J. Charles, and T. M. Cahill (2006), A sensitive method for the quantification of acrolein and other volatile carbonyls in ambient air, Anal. Chem., 78, 2405-2412, doi:10.1021/ac051947s.
Sinreich, R., R. Volkamer, F. Filsinger, U. Frieß, C. Kern, U. Platt, O. Sebastián, and T. Wagner (2007), MAX-DOAS detection of glyoxal during ICARTT 2004, Atmos. Chem. Phys., 7, 1293-1303.

Sorooshian, A., et al. (2006), Oxalic acid in clear and cloudy atmospheres: Analysis of data from International Consortium for Atmospheric Research on Transport and Transformation 2004, J. Geophys. Res., 111, D23S45, doi:10.1029/2005JD006880.

Sorooshian, A., N. L. Ng, A. W. H. Chan, G. Feingold, R. C. Flagan, and J. H. Seinfeld (2007), Particulate organic acids and overall water-soluble aerosol composition measurements from the 2006 Gulf of Mexico Atmospheric Composition and Climate Study (GoMACCS), J. Geophys. Res., 112, D13201, doi:10.1029/2007JD008537.

Spaulding, R. S., R. W. Talbot, and M. J. Charles (2002), Optimization of a mist chamber (cofer scrubber) for sampling water-soluble organics in air, Environ. Sci. Technol., 36, 1798-1808.

Spaulding, R. S., G. W. Schade, A. H. Goldstein, and 2003. Charles (2003), Characterization of secondary atmospheric photooxidation products: Evidence for biogenic and anthropogenic sources, J. Geophys. Res., 108(D8), 4247, doi:10.1029/2002JD002478.

Tadić, J., G. K. Moortgat, and K. Wirtz (2006), Photolysis of glyoxal in air, J. Photochem. Photobiol. A Chem., 177, 116-124, doi:10.1016/ j.jphotochem.2005.10.010.

Thornton, J. A., et al. (2002), Ozone production rates as a function of NOx abundances and HOx production rates in the Nashville urban plume, J. Geophys. Res., 107(D12), 4146, doi:10.1029/2001JD000932.

Tsigaridis, K., and M. Kanakidou (2003), Global modeling of secondary organic aerosol in the troposphere: a sensitivity analysis, Atmos. Chem. Phys., 3, 1849-1869.

Tsigaridis, K., and M. Kanakidou (2007), Secondary organic aerosol importance in the future atmosphere, Atmos. Environ, 41, 46824692, doi:10.1016/j.atmosenv.2007.03.045

Tuazon, E. C., H. Mac Leod, R. Atkinson, and W. P. L. Carter (1986), $\alpha$-dicarbonyl yields from the $\mathrm{NO}_{\mathrm{x}}$-air photooxidations of a series of aromatic hydrocarbons in air, Environ. Sci. Technol., 20(4), 383-387. van der Werf, G. R., J. T. Randerson, G. J. Collatz, and P. S. Kasibhatla (2006), Interannual variability in global biomass burning emission from 1997 to 2004, Atmos. Chem. Phys., 6, 3423-3441.

Volkamer, R., U. Platt, and K. Wirtz (2001), Primary and secondary glyoxal formation from aromatics: Experimental evidence for the bicycloalkylradical pathway from benzene, toluene, and p-xylene, J. Phys. Chem. A, $105,7865-7874$

Volkamer, R., P. Spietz, J. P. Burrows, and U. Platt (2005a), Highresolution absorption cross-section of glyoxal in UV-vis and IR spectra ranges, J. Photochem. Photobiol. A. Chem., 172, 35-36, doi:10.1016/ j.jphotochem.2004.11.011.

Volkamer, R., L. T. Molina, M. J. Molina, T. Shirley, and W. H. Brune (2005b), DOAS measurement of glyoxal as an indicator for fast VOC chemistry in urban air, Geophys. Res. Lett., 32, L08806, doi:10.1029/ 2005GL022616.

Volkamer, R., J. L. Jimenez, F. San Martini, K. Dzepina, Q. Zhang, D. Salcedo, L. T. Molina, D. R. Worsnop, and M. J. Molina (2006), Secondary organic aerosol formation from anthropogenic air pollution: Rapid and higher than expected, Geophys. Res. Lett., 33, L17811, doi:10.1029/2006GL026899.

Volkamer, R., F. San Martini, L. T. Molina, D. Salcedo, J. L. Jimenez, and M. J. Molina (2007), A missing sink for gas-phase glyoxal in Mexico City: Formation of secondary organic aerosol, Geophys. Res. Lett., 34, L19807, doi:10.1029/2007GL030752.

Wang, Y., D. J. Jacob, and J. A. Logan (1998), Global simulation of tropospheric $\mathrm{O}_{3}-\mathrm{NO}_{\mathrm{x}}$-hydrocarbon chemistry: 1. Model formulation, J. Geophys. Res., 103(D9), 10,713-10,726.

Warneck, P. (2005), Multi-phase chemistry of $\mathrm{C}_{2}$ and $\mathrm{C}_{3}$ organic compounds in the marine atmosphere, J. Atmos. Chem., 51, 119-159, doi:10.1007/s10874-005-5984-7.

Wesely, M. L. (1989), Parameterization of surface resistance to gaseous dry deposition in regional-scale numerical models, Atmos. Environ., 23, $1293-1304$

Wiedinmyer, C., A. Guenther, P. Harley, N. Hewitt, C. Geron, P. Artaxo, R. Steinbrecher, and R. Rasmussen (2004), Global organic emissions from vegetation, pp. 115-170, in Emissions of Atmospheric Trace Compounds, edited by C. Granier, P. Artaxo, and C. Reeves, 544 pp., Springer, Dordrecht, Netherlands.

Wild, O., X. Zhu, and M. J. Prather (2000), Fast-J: Accurate simulation of in- and below-cloud photolysis in tropospheric chemical models, J. Atmos. Chem., 37, 245-282.

Wittrock, F. (2006), The retrieval of oxygenated volatile organic compounds by remote sensing techniques, Ph.D. thesis, University of Bremen, Bremen Germany, May 2006, available at http://nbn-resolving.de/urn:nbn:de: gbv:46-diss000104818. 
Wittrock, F., A. Richter, H. Oetjen, J. P. Burrows, M. Kanakidou, S. Myriokefalitakis, R. Volkamer, S. Beirle, U. Platt, and T. Wagner (2006), Simultaneous global observations of glyoxal and formaldehyde from space, Geophys. Res. Lett., 33, L16804, doi:10.1029/ 2006GL026310.

Xiao, Y., D. J. Jacob, and S. Turquety (2007), Atmospheric acetylene and its relationship with $\mathrm{CO}$ as an indicator of air mass age, J. Geophys. Res., 112, D12305, doi:10.1029/2006JD008268.

Yevich, R., and J. A. Logan (2003), An assessment of biofuel use and burning of agricultural waste in the developing world, Global Biogeochem. Cycles, 17(4), 1095, doi:10.1029/2002GB001952.

Yu, J., H. E. Jeffries, and K. G. Sexton (1997), Atmospheric photooxidation of alkylbenzenes - I. Carbonyl product analyses, Atmos. Environ., 31(15), 2261-2280.

Yu, J., R. C. Flagan, and J. H. Seinfeld (1998), Identification of products containing $-\mathrm{COOH},-\mathrm{OH}$, and $-\mathrm{C}=\mathrm{O}$ in atmospheric oxidation of hydrocarbons, Environ. Sci. Technol., 32(16), 2357-2370.

Yu, J. Z., X.-F. Huang, J. Xu, and M. Hu (2005), When aerosol sulfate goes up, so does oxalate: Implication for the formation mechanisms of oxalate, Environ. Sci. Technol., 38, 128-133.

Yuan, Z. B., J. Z. Yu, A. K. H. Lau, P. K. K. Louie, and J. C. H. Fung (2006), Application of positive matrix factorization in estimating aerosol secondary organic carbon in Hong Kong and its relationship with secondary sulfate, Atmos. Chem. Phys., 6, 25-34.

Zhang, Q., D. R. Worsnop, M. R. Canagaratna, and J. L. Jimenez (2005), Hydrocarbon-like and oxygenated organic aerosols in Pittsburgh: Insight into sources and processes of organic aerosols, Atmos. Chem. Phys., 5, $3289-3311$
Zhao, J., R. Zhang, K. Misawa, and K. Shibuya (2005), Experimental product study of the $\mathrm{OH}$-initiated oxidation of m-xylene, J. Photochem. Photobio. A Chem., 176(1-3), 199-207, doi:10.1016/j.jphotochem.2005.07.013.

Zhao, J., N. P. Levitt, R. Y. Zhang, and J. M. Chen (2006), Heterogeneous reactions of methylglyoxal in acidic media: Implications for secondary organic aerosol formation, Environ. Sci. Technol., 40, 7682-7687.

Zhou, X., and K. Mopper (1990a), Measurement of sub-parts-per-billion levels of carbonyl compounds in marine air by a simple cartridge trapping procedure followed by liquid chromatography, Environ. Sci. Technol., 24, $1482-1485$

Zhou, X., and K. Mopper (1990b), Apparent partition coefficients of 15 carbonyl compounds between air and seawater and between air and freshwater; implications for air-sea exchange, Environ. Sci. Technol., 24, $1864-1869$

Zhou, X., and K. Mopper (1997), Photochemical production of low-molecular-weight carbonyl compounds in seawater and surface microlayer and their air-sea exchange, Mar. Chem., 56, 201-213.

J. P. Burrows, M. Vrekoussis, and F. Wittrock, Institute of Environmental Physics and Remote Sensing, University of Bremen, Otto-Hahn-Allee 1, D-28334 Bremen, Germany.

T.-M. Fu, Department of Civil and Structural Engineering, The Hong Kong Polytechnic University, Hung Hom, Kowloon, Hong Kong. (cetmfu@ polyu.edu.hk)

D. K. Henze, NASA Goddard Institute for Space Studies and the Earth Institute, Columbia University, 2880 Broadway, New York, NY 10025, USA.

D. J. Jacob, Department of Earth and Planetary Sciences, Harvard University, 29 Oxford Street, Cambridge, MA 02138, USA. 